\title{
10. KIEMELT FIGYELMET IGÉNYLŐ TANULÓK MÉLTÁNYOS FEJLESZTÉSE
}

\author{
DOBOSNÉ FÖLDI BRIGITTA
}

\section{Bevezetés}

Napjainkban nagy hangsúly helyeződik a tanulókkal való egyéni bánásmódra a nevelés-oktatás során. A gyermekek különbözőségeit figyelembe véve fontos a megfelelő fejlesztés, ami kizárólag úgy valósulhat meg, ha figyelembe vesszük a tanulók egyéni szükségleteit, különbségeit. Kutatásunkban arra szerettük volna megtalálni a választ, hogy mennyire játszik fontos szerepet a fejlesztő iskolák tekintetében az egyéni képességfejlesztés, és hogyan jelenik meg mindez a gyakorlóiskolában. Hogyan próbálják a különleges bánásmódot igénylő gyermekek fejlesztését megvalósítani, és mit tesz az iskola a hátrányos helyzetü gyermekek integrálása érdekében? Az egyetem és a gyakorló hogyan készíti fel a hallgatókat a kiemelt figyelmet igénylő tanulók fejlesztésére? Hogyan ítélik meg a tanárok, szülők és az ott tanuló diákok az iskolában zajló egyéni fejlesztést, tehetséggondozást?

\section{Kiemelt figyelmet igénylő tanulók és méltányosság}

Témánk mélyebb megismeréséhez szükséges megvizsgálni azokat a fogalmakat, amelyek elengedhetetlenek a megfelelő értelmezéshez. Először is tisztáznunk kell kiket értünk kiemelt figyelmet igénylő tanulók alatt.

A köznevelési törvény külön foglalkozik a kiemelt figyelmet igénylő tanulók oktatásával, nevelésével. A nemzeti köznevelésről szóló 2011. évi CXC. törvény 6. \$ (12) bekezdése két nagy csoportot határoz meg a következőképpen:

- A különleges bánásmódot igénylő gyermekek közé sorolja a sajátos nevelési igényű, beilleszkedési, tanulási, magatartási nehézséggel küzdő, valamint a kiemelten tehetséges tanulókat.

1. „sajátos nevelési igényü gyermek, tanuló: az a különleges bánásmódot igénylo” gyermek, tanuló, aki a szakértői bizottság szakértői véleménye alapján mozgásszervi, érzékszervi (látási, hallási), értelmi vagy beszédfogyatékos, több fogyatékosság együttes elöfordulása 
esetén halmozottan fogyatékos, autizmus spektrum zavarral vagy egyéb pszichés fejlo"dési zavarral (súlyos tanulási, figyelem-vagy magatartásszabályozási zavarral) küzd

2. beilleszkedési, tanulási, magatartási nehézséggel küzdö gyermek, tanuló: az a különleges bánásmódot igénylö gyermek, tanuló, aki a szakértöi bizottság szakértöi véleménye alapján az életkorához viszonyitottan jelentösen alulteljesit, társas kapcsolati problémákkal, tanulási, magatartásszabályozási hiányosságokkal küzd, közösségbe való beilleszkedése, továbbá személyiségfejlödése nehezitett vagy sajátos tendenciákat mutat, de nem minösül sajátos nevelési igényünek

3. kiemelten tehetséges gyermek, tanuló: az a különleges bánásmódot igénylö gyermek, tanuló, aki átlag feletti általános vagy speciális képességek birtokában magas fokú kreativitással rendelkezik, és felkelthetö benne a feladat iránti erös motiváció, elkötelezettség" (Köznevelési törvény, 2011, 4\$).

- A másik nagy csoportba tartoznak a gyermekek védelméről és a gyámügyi igazgatásról szóló 1997. évi XXXI. törvény szerint hátrányos és halmozottan hátrányos helyzetü gyermekek, tanulók. A törvény 2013. évi módosításában a 67/A. \a következőképpen határozza meg és egészíti ki a fenti fogalmakat.

1. „Hátrányos helyzetü az a rendszeres gyermekvédelmi kedvezményre jogosult gyermek és nagykorúvá vált gyermek, aki esetében az alábbi körülmények közül egy fennáll: a) a szülö vagy a családbafogadó gyám alacsony iskolai végzettsége, ha a gyermeket együtt nevelö mindkét szülöröl, a gyermeket egyedül nevelö szülöröl vagy a családbafogadó gyámról - önkéntes nyilatkozata alapján - megállapitható, hogy a rendszeres gyermekvédelmi kedvezmény igénylésekor legfeljebb alapfokú iskolai végzettséggel rendelkezik, b) a szülö vagy a családbafogadó gyám alacsony foglalkoztatottsága, ha a gyermeket nevelo" szülök bármelyikéröl vagy a családbafogadó gyámról megállapitható, hogy a rendszeres gyermekvédelmi kedvezmény igénylésekor az Szt. 33. S-a szerinti aktív korúak ellátására jogosult vagy a rendszeres gyermekvédelmi kedvezmény igénylésének idöpontját megelözö 16 hónapon belül legalább 12 hónapig álláskeresöként nyilvántartott személy, c) a gyermek elégtelen lakókörnyezete, illetve lakáskörülményei, ha megállapitható, hogy a gyermek a településre vonatkozó integrált városfejlesztési stratégiában szegregátumnak nyilvánitott lakókörnyezetben vagy félkomfortos, komfort nélküli vagy szükséglakásban, illetve olyan lakáskörülmények között él, ahol korlátozottan biztositottak az egészséges fejlödéséhez szükséges feltételek.

2. Halmozottan hátrányos helyzetü a) az a rendszeres gyermekvédelmi kedvezményre jogosult gyermek és nagykorúvá vált gyermek, aki esetében az (1) bekezdés a) -c) pontjaiban meghatározott körülmények közül legalább kettö fennáll, b) a nevelésbe vett gyermek, c) az utógondozói ellátásban részesüló és tanulói vagy hallgatói jogviszony- 
ban álló fiatal felnött. (3) A gyámhatóság a rendszeres gyermekvédelmi kedvezményre való jogosultság elbirálásával egyidejüleg kérelemre - külön döntésben, a rendszeres gyermekvédelmi kedvezményre való jogosultsággal egyezö idötartamra - megállapitja a gyermek, nagykorúvá vált gyermek hátrányos vagy halmozottan hátrányos helyzetének fennállását." (GYvt. 1997. évi XXXI. tv.)

Réthy (2020) tanulmányában, azonban felhívja a figyelmet arra, hogy a törvénybe foglaltakhoz képest a kiemelt figyelmet igénylö tanulók köre tágabb, kiterjedtebb. A törvényben nem szerepel a szocioökonómiai, szociokulturális hátrányban élők, a kisebbségi közösségekhez tartozó és a nyelvi hátrányban lévő tanulók csoportja. Mindezek ismeretében célszerủ lenne a kiemelt figyelmet igénylő gyermekek körének bővítése. (Réthy, 2020)

A 15/2013. (II. 26.) EMMI rendelet a pedagógiai szakszolgálati intézmények működéséről pontosan meghatározza a szakértői bizottságok tevékenységét, amelyek különböző standardizált tesztek, megfigyelések, dokumentumelemzések stb. segítségével határozatot hozhatnak az SNI, BTMN megállapításáról vagy kizárásáról. Külön tárgyalja a tehetséges gyermekek esetén az intézmények feladatait, mint például a korai tehetségazonosítás, tehetséges gyermekek személyiségfejlődésének támogatása, tanácsadás és támogatás a szülők részére stb.

A NAT (2020) tartalmazza az egységesség és differenciálás módszertani alapelveit. Az egyik legfontosabb feladat a pedagógusok számára a különleges bánásmódot igénylő tanulók esetében a tantárgyi tartalmak egyéni sajátosságokhoz való illesztése. Az adaptálás és differenciálás segít az egyéni haladási ütem biztosításában, de szintén kiemelt jelentőségű a szakemberek bevonása a nevelési-oktatási folyamatba. A NAT (2020) megfogalmazza, hogy az iskolának enyhítenie kell az esetleges hátrányokat, optimális esetben ki is kell küszöbölni azokat. Ezek közül külön kiemeli a településszerkezeti hátrányból eredő, kulturális, nyelvi elsajátításhoz köthető, valamint a különleges bánásmódot igénylő tanulók egyéni sajátosságokhoz illeszkedő fejlesztő tevékenységét. Fontos alapelvként tekint az egyénre szabott tanulási lehetőségek biztosítására, amelyhez olyan pedagógusok meglétét feltételezi, akik rendelkeznek az ehhez szükséges szemléletmóddal, kompetenciákkal. A 2020-as NAT-hoz illeszkedő irányelveket találunk az SNI-tanulók oktatásához, valamint szakmai ajánlást a beilleszkedési, tanulási, magatartási nehézséggel küzdő gyermekek, tanulók neveléséhez-oktatásához. Az SNI-tanulók oktatásához tartozó irányelvek a következő alcsoportok fejlesztését foglalják magukban: látási fogyatékos, egyéb pszichés fejlödési zavarral küzdő, középsúlyos értelmi fogyatékos, mozgásszervi fogyatékos, autizmus spektrum zavarral küzdő, súlyos és halmozottan súlyos értelmi fogyatékos, enyhe értelmi fogyatékos, hallási fogyatékos, valamint beszédfogyatékos tanulók. A beilleszkedési, tanulási, magatartási nehézséggel küzdő gyermekek típusai szintén megtalálhatóak az ajánlásban. Ezek a következők: olvasási-szövegértési nehézség, írás-helyesírási nehézség; számolási nehézség; figyelmi nehézség; beilleszkedési, magatartási nehézség; valamint súlyos környezeti ártalom. 
Következtetésként elmondható, hogy a kiemelt figyelmet igénylő tanulók köre egyre bővül, növekvő tendenciát mutat, ezért egy szakmai fejlesztő iskola tekintetében hatványozottan fontos a tanulók egyéni sajátosságaihoz való alkalmazkodás.

„Vannak olyan gyermekek, akiknek állandó vagy átmeneti jelleggel fizikai, biológiai, pszichikai, intellektuális, családi vagy szociokulturális okok miatt egyéni, sajátos nevelési-oktatási szükségleteik vannak, ezért a speciális nevelési-oktatási szükségletekhez, sajátosságokhoz egyénenként igazodó bánásmódot igényelnek az iskolában. Öket nevezzük különleges bánásmódot igénylö gyermekeknek." (Falus [szerk.], 1998. 305.)

Tanulmányunkban azokra a tanulókra fókuszálunk, akik hátrányos helyzetűek, vagy különleges bánásmódot igényelnek tehetségük vagy tanulási nehézségeik miatt. A téma jelentősége vitathatatlan, hiszen, mint tudjuk, a magyar oktatási rendszer rendkívül szelektív, hatalmas különbségek vannak mind az iskolák, mind a tanulók között (Báthory,1997). Erre világítanak rá Csapó és mtsai. (2014) egy, az iskolai teljesítmények vizsgálatáról szóló tanulmányukban. Az ESCS-index, mely a tanulók családi hátterét jellemzi, valamint a tanulók PISA-teszteken elért eredményei megmutatták, hogy szoros összefüggés van a tanulói teljesítmény és a családi háttértényezők között, ugyanakkor a tanulók teljesítménye átlag alatti Magyarországon (Csapó és mtsai., 2014). Az OECD jelentésben olvashatjuk, hogy a magas fokú méltányosság hozzájárul a jobb teljesítményhez, és a jól teljesítő országok kiemelkedően teljesítenek az egyenlő esélyek biztosítása, a különbségek figyelembevétele terén $(O E C D, 2013)$.

Az iskolai gyakorlatban is egyre fontosabbá válik a gyermekek képességeihez igazodó oktatás, értékelés, a differenciálás, az egyéni bánásmód, a tehetségek kibontakoztatása, a felzárkóztatás, valamint az eltérő szociális hátterű tanulók méltányos fejlesztése, különösen akkor, ha fejlesztő iskolákról beszélünk. Hogyan lehetséges a tanulók egyéni, méltányos fejlesztése? Milyen példával járjon elöl egy szakmai fejlesztő iskola, ami más intézmények számára is követhető utat mutat?

Réthy Endréné és Vámos Ágnes (2006) szerint méltányos fejlesztés csakis olyan iskolában valósulhat meg, ahol megfelelően képzett pedagógusok oktatnak megfelelő minőségben. A méltányos pedagógia feladata egy ún. védőháló (1. ábra) létrehozása, megszüntetve a kirekesztést, intoleranciát és szegregációt, ugyanakkor adaptív, befogadó, a sajátos nevelési igényeket figyelembe vevő környezet megteremtése. 


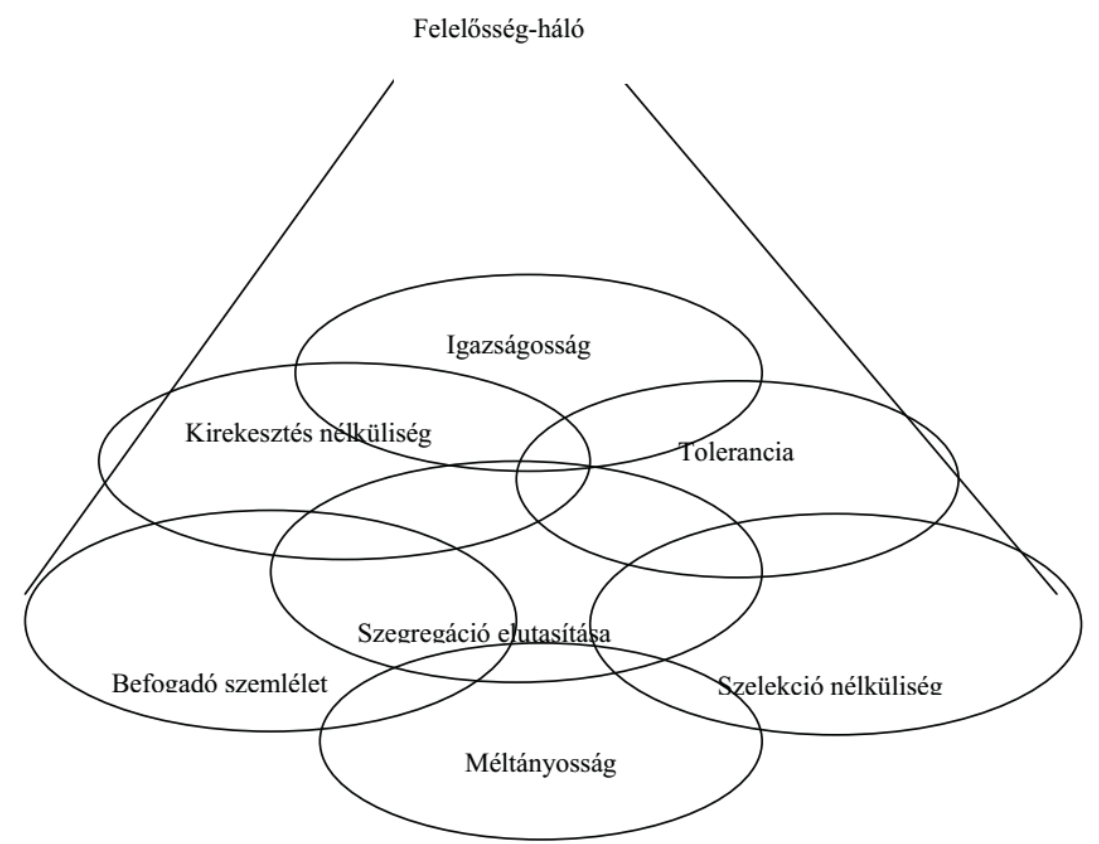

10.1. ábra: A pedagógiai felelősség mint védőháló (Réthy és Vámos, 2006. 45.)

A méltányos pedagógia egyenlő esélyt teremt minden diákja számára. E szemléletet elötérbe helyezi azt, hogy minden gyermeket értékrendjéhez alkalmazkodva kell segíteni a fejlődés útján, hiszen ez a jog őt megilleti (Réthy és Vámos, 2006). Lannert (2004) megfogalmazza, hogy erre leginkább olyan iskola képes, amely az inklúzió jegyében müködik. Egy ilyen elfogadó, befogadó intézményben összhangba kerül az eredményesség és méltányosság, hiszen mindenki a neki megfelelő oktatásban részesül, s ezáltal az egyén a lehető legjobb teljesítményt fogja elérni.

Minden tanuló más és más, ezért az iskolának is arra kell törekednie, hogy az összes tanuló a számára megfelelő nevelésben és oktatásban részesüljön, s ezáltal elérje teljesítőképessége maximumát. Murray egy 1993-as tanulmányában leírja, hogy a szakmai fejlesztő iskolákkal szemben milyen kritériumokat várhatunk el. Világosan megfogalmazza, hogy ezekben az iskolában tanító pedagógusoknak egyaránt fontosnak kell tartaniuk tanítványaik fejlesztését, függetlenül azok képességeitől, motiváltságától s attól, hogy nehéz vagy könnyű a tanításuk. A tanítás folyamatában elengedhetetlen a tanulók egyéni szükségleteinek és képességeinek figyelembevétele.

Kotschy Beáta (2003) megfogalmazza, hogy jelenleg nincsenek kialakulva még erre vonatkozó jó gyakorlatok. A pedagógusok képzésének is csupán töredéke vonatkozik a sajátos igényekkel rendelkező tanulókkal kapcsolatos pedagógiai kérdésekre, $s$ a gyakorlatban való alkalmazási lehetőségek szinte egyáltalán nem jelennek meg. 
Az NCRST (National Comission On Research Science And Technology) egyik tanulmánya a fejlesztő iskolákról leírja, hogy a gyermekek számára olyan módon kell biztosítani a tanulás lehetőségét, ahogyan az egyén számára az a legkedvezőbb, tiszteletben tartva a különböző nemhez, társadalmi osztályhoz, etnikumhoz vagy kultúrához való tartozást (NCREST, 1993). Néhány kutató pedig egyenesen úgy véli, ezeknek az iskoláknak nem csupán figyelembe kell venni, hanem kifejezetten tükröznie kell a társadalmi összetételt. Fontosnak tartják, hogy ezen iskolákban jelenjenek meg a tanulók közötti földrajzi (falu, város), etnikai és társadalmi osztályok szerinti különbségek (Young, 1990).

A fentiek alapján elmondhatjuk, hogy a szakmai fejlesztő iskolákban még fokozottabban kell odafigyelni az egyéni bánásmódra. Már nem az ugyanúgy, ugyanazt mindenkinek elv mentén kell tanítani, hanem teljes mértékben az egyénekre koncentrálni s őket a lehető legmagasabb szintre fejleszteni. Ehhez természetesen szükség van olyan innovatív, nyitott pedagógusokra, akik képesek facilitátorként működni az osztályokban és minden egyes gyermeket a számára legmegfelelőbb oktatásban részesíteni.

\section{Kutatás}

Kutatásunk céljait a következő pontokban fogalmaztuk meg:

1. A kiemelt figyelmet igénylő tanulók méltányos fejlesztése megjelenési módjainak feltárása az iskolai dokumentumokban.

2. A pedagógusok nézetei a különleges bánásmódot igénylő gyermekek fejlesztéséről s annak tényleges megvalósulásáról. Mit tesz az iskola hátrányos helyzetű gyermekek integrálása érdekében, hogyan segíti a különleges bánásmódot igénylő tanulókat az előrehaladásban?

3. Az iskolai dokumentumokban leírtak, valamint a megvalósulás összefüggéseinek vizsgálata.

4. A tanulók véleménye a gyakorlóiskolában zajló egyéni fejlesztésről, tehetséggondozásról.

5. A hallgatók felkészítése a kiemelt figyelmet igénylő tanulók fejlesztésére. Hogyan segíti az egyetem, és hogyan segíti a gyakorlóiskola őket? Kapcsolatban áll-e a kettő egymással?

6. A szülők megítélése a gyakorlóiskolában történő tehetséggondozást, felzárkóztatást, méltányos fejlesztést illetően.

Ezek a kutatási célok megfelelő alapul szolgálhatnak számunkra, hogy mélyebben megismerkedjünk témánkkal egy tipikus gyakorlóiskola tükrében, s a későbbiek folyamán segítséget nyújtsanak abban, hogy egy szakmai fejlesztő iskola létrehozásához megfelelő javaslatokat tudjunk megfogalmazni az elemzéseket követően. 


\section{Kutatásunk hipotézisei a következők:}

H1: Az iskolai dokumentumokban jelentős mértékben találunk információkat a kiemelt figyelmet igénylő tanulók fejlesztéséről.

H2: A pedagógusok fontosnak ítélik meg a kiemelt figyelmet igénylő tanulók fejlesztését szakmai tevékenységük során.

H3: Az iskolai dokumentumokban kijelölt célok szoros összefüggésben állnak a pedagógusok gyakorlatban megvalósított fejlesztő tevékenységével.

H4: A pedagógusok kiemelt figyelmet igénylő tanulókról alkotott nézetei összefüggésben állnak a gyakorlatban megvalósított fejlesztő tevékenységükkel.

H5: A pedagógusok nagyobb igényt tartanak a különleges bánásmódot igénylő gyerekek fejlesztésével kapcsolatos továbbképzésekre.

H6: A diákok elégedettek a gyakorlóiskolában folyó fejlesztő tevékenyéggel.

H7: A pedagógusjelöltek kevésbé vesznek részt a gyakorlóiskolában lévő tehetséggondozó, felzárkóztató foglalkozásokon.

H8: Az egyetemi képzés és a gyakorlóiskola közötti összhang alacsony szintű.

H9: A szülők fontosnak tartják a kiemelt figyelmet igénylő tanulók fejlesztését az iskolaválasztásnál.

\section{Eredmények}

Kutatásunk eredményeinek bemutatásához először ismertetjük azt a logikai vázat, amely mentén az adatok feldolgozása megtörtént. A kiemelt figyelmet igénylő tanulók méltányos fejlesztését először az iskolai dokumentumokban való megjelenés szempontjából vizsgáljuk meg. Ezután a pedagógusok nézeteit ismertetjük a téma vonatkozásában, majd összehasonlítjuk a dokumentumokban való célkitűzésekkel. A pedagógusok véleményét követően a gyakorlóiskolás diákok, az egyetemi hallgatók, valamint a szülők válaszaiból nyert adatok összefüggéseit írjuk le. A kutatásban megvizsgáljuk pontosan, hogy a különböző csoportok milyen eltéréseket vagy összefüggéseket mutatnak az általunk vizsgált területeken. Fontosnak tartottuk, hogy minden, a kutatásban részt vevő pedagógus, diák, hallgató, szülő nézeteit megismerjük a témánkkal kapcsolatban, hiszen ezek az egyes csoportoknál más-más képet mutathatnak. Úgy gondoltuk, vizsgálatunk során árnyaltabb képet kaphatunk a kiemelt figyelmet igénylő tanulók fejlesztéséről s annak megvalósulásáról, valamint az esetleges hiányosságokról, mely hozzásegíthet bennünket ahhoz, hogy megfelelő javaslatokat tudjunk megfogalmazni a jövőre vonatkozóan. 


\subsection{A kiemelt figyelmet igénylő tanulók fejlesztésének megjelenése az iskolai dokumentumokban}

Témánk szempontjából fontosnak tartottuk áttekinteni az iskolai dokumentumokat olyan aspektusból, hogy milyen célokat tűznek ki maguk elé a gyakorlóiskolában tanító pedagógusok a tehetséggondozás, felzárkóztatás területén. Mennyire játszik fontos szerepet az intézmény életében a kiemelt figyelmet igénylő tanulókkal való foglalkozás? Hogyan jelennek meg ezek a szempontok az iskolai dokumentumokban?

Az elemzett dokumentumok a következők voltak:

- Eszterházy Károly gyakorlóiskola munkaterve,

- Eszterházy Károly gyakorlóiskola pedagógiai programja,

- Eszterházy Károly gyakorlóiskola szervezeti és működési szabályzata,

Eszterházy Károly gyakorlóiskola tanulmányi és sportverseny eredményei.

- A dokumentumok elemzéséhez a következő megfigyelési szempontokat állítottuk fel:

- a kiemelt figyelmet igénylő tanulók fejlesztésének megjelenése a pedagógiai célok között,

- pedagógusok feladatai a tehetséggondozás, felzárkóztatás területén,

- a téma munkaköri leírásokban való megjelenése,

- hallgatók felkészítése a kiemelt figyelmet igénylő tanulók fejlesztésére.

A fenti szempontok alapján kezdtük el megvizsgálni az iskolai dokumentumokat. Elsőként azt figyeltük meg hogyan jelenik meg témánk a kitűzött pedagógiai célokban. Az iskola munkatervében egyik legfőbb célként tűzték ki a pedagógusok a versenyekre való felkészítést és az azokon való részvételt. Összesen 156 féle verseny jelent meg a gyakorlóiskola munkatervében, melyre a felkészítő tanárok nevével együtt a teljes évre kidolgozott programtervezetet találtunk. Ezek között voltak helyi, megyei, országos, tantárgyi, művészeti, diákolimpiai és természetjáró versenyek is.

Ezzel összhangba hozható a tanulmányi és sportversenyek eredményeiről készült dokumentum, melynek a 2015/16-os tanév összesítő táblázatait az alábbiakban láthatjuk:

\begin{tabular}{|l|c|c|c|c|c|}
\hline Tanulmányi & Városi & Megyei & Területi & Regionális & Országos \\
\cline { 2 - 6 } versenyek száma & 8 & 129 & 28 & 12 & 39 \\
\hline
\end{tabular}

10.1. táblázat: Tanulmányi versenyek a gyakorlóiskolában

\begin{tabular}{|l|c|c|c|c|l|}
\hline \multirow{2}{*}{$\begin{array}{l}\text { Sportversenyek } \\
\text { száma }\end{array}$} & Városi & Megyei & Területi & Országos & Nemzetközi \\
\cline { 2 - 6 } & 41 & 19 & 11 & 9 & 1 \\
\hline
\end{tabular}

10.2. táblázat: Sportversenyek a gyakorlóiskolában 
A táblázatokból (1. táblázat, 2. táblázat) kiderül, hogy nemcsak a munkatervben kitűzött célok között jelenik meg a sokféle verseny, hanem a gyakorlatban is megvalósításra kerülnek azok. Ráadásul elmondhatjuk, hogy szép eredményekkel szerepelnek a gyakorlós diákok ezeken a versenyeken. A megyei tanulmányi versenyeken 129 közül 73 az 1.-3. helyezések valamelyike, ami igen magas számnak mondható, de országos szinten is kimagasló, hiszen a 39-ből 17-en értek el dobogós helyet. A sportversenyek szintén fontos szerepet töltenek be az iskola életében, melyeken már nemzetközi versenyzők is megjelennek.

A munkatervben találtunk még a minőségirányítási programhoz kapcsolódó megfogalmazott célokat is. Ezek a következők voltak:

- „A tanulási problémák hatékonyabb kezelése, szorosabb együttmüködés a fejlesztö csoport tagjaival. Szükség esetén egyéni fejlesztést biztositó fejlesztési terv készitése a sikeresebb felzárkóztatás érdekében, ezzel az esélyegyenlöség megteremtése."

- „A tanitási órákon törekszünk a pozitiv teljesitményt motiváló értékelési gyakorlat kialakitására, a fejlesztö értékelés tudatos alkalmazására."

- "A tanulók tudatos felkészitése a városi, területi, regionális és országos versenyekre." (Munkaterv, 2015. 32-33)

Az intézmény pedagógiai programjában kiemelt célként jelenik meg az egyén személyiségének fejlesztése, figyelembe véve a tanulók különbözö szintü adottságait, valamint az eltérö mértékü fejlödést. Ezek alapján elmondhatjuk, hogy a tanulók méltányos fejlesztése igen előkelő helyen áll a gyakorlóiskola céljainak tekintetében.

Szerettük volna megvizsgálni azt is, hogy a pedagógusoknak milyen feladatai vannak a gyakorlóiskolában a kiemelt figyelmet igénylö tanulókkal kapcsolatban. Ennek megfigyeléséhez leginkább a pedagógiai programban leírtak voltak segítségünkre. A pedagógusok alapvető feladatai között helyet kapott mind a tehetséggondozás, mind a halmozottan hátrányos helyzetű, beilleszkedési, magatartási és tanulási nehézséggel küzdő, valamint a felzárkóztatásra szoruló tanulók eredményes fejlesztése.

A tehetséges tanulók gondozása a gyakorlóiskola pedagógiai programjában:

- Egyéb (tanórán kivüli) fejlesztö foglalkozások szervezése a tehetséges tanulók részére.

- Iskolai tanulmányi, sport-és kulturális versenyek, vetélkedök, bemutatók, pályázatok önálló szervezése, segitség a szervezésben.

- Részvétel az iskolai tanulmányi, sport-és kulturális versenyeken, vetélkedökön, bemutatókon.

- A tehetséges tanulók részvételének biztositása és felkészitése a különféle iskolán belüli versenyekre, vetélkedökre stb.

- A tehetséges tanulók részvételének biztositása és felkészitése a különféle iskolán kivüli versenyekre, vetélkedökre stb. (Ped. pr. 2015. 36.). 
A hátrányos helyzetü, a halmozottan hátrányos helyzetü, valamint a beilleszkedési, magatartási és tanulási nehézségekkel küzdő tanulók, illetve a felzárkóztatásra szoruló tanulók gondozása, eredményes fejlesztése az intézmény pedagógiai programjában:

- Egyéb (tanórán kivüli) fejlesztö foglalkozások szervezése a hátrányos helyzetü, a halmozottan hátrányos helyzetü, valamint a beilleszkedési, magatartási és tanulási nehézségekkel küzdö tanulók, illetve a felzárkóztatásra szoruló tanulók részére.

- A gyermekvédelmi feladatok ellátása a hátrányos helyzetü, a halmozottan hátrányos helyzetü, valamint a beilleszkedési, magatartási és tanulási nehézségekkel küzdö tanulók, illetve a felzárkóztatásra szoruló tanulók körében.

- A hátrányos helyzetü, a halmozottan hátrányos helyzetü, valamint a beilleszkedési, magatartási és tanulási nehézségekkel küzdö tanulók, illetve a felzárkóztatásra szoruló tanulók korrepetálása, segitése, mentorálása.

- A hátrányos helyzetü, a halmozottan hátrányos helyzetü, valamint a beilleszkedési, magatartási és tanulási nehézségekkel küzdö tanulók, illetve a felzárkóztatásra szoruló tanulók felkészitése javitó vagy osztályozó vizsgára.

- Az eredményes középiskolai felvétel elösegitése a hátrányos helyzetü, a halmozottan hátrányos helyzetü, valamint a beilleszkedési, magatartási és tanulási nehézségekkel küzdö tanulók körében (Ped. pr., 2015. 36-37.).

Külön az osztályfőnöki feladatoknál is megjelennek a témánkkal kapcsolatos elvárások. Az osztályfőnököknek figyelemmel kell kísérniük az osztályba járó kiemelt figyelmet igénylő tanulókat, segíteni és támogatni őket mindenben.

Az iskola pedagógia programjának egy külön fejezete foglalkozik a kiemelt figyelmet igénylő tanulók oktatásával, nevelésével. A következő táblázatokban megpróbáltuk összefoglalni egyrészt a sajátos nevelési igényű gyermekekre vonatkozó fejlesztési célokat, feltételeket, másrészt azokat a tevékenységeket, melyek a tehetségek, hátrányos helyzetü tanulók és beilleszkedési és magatartási nehézségekkel küzdő gyermekek fejlődését segítik elő. 


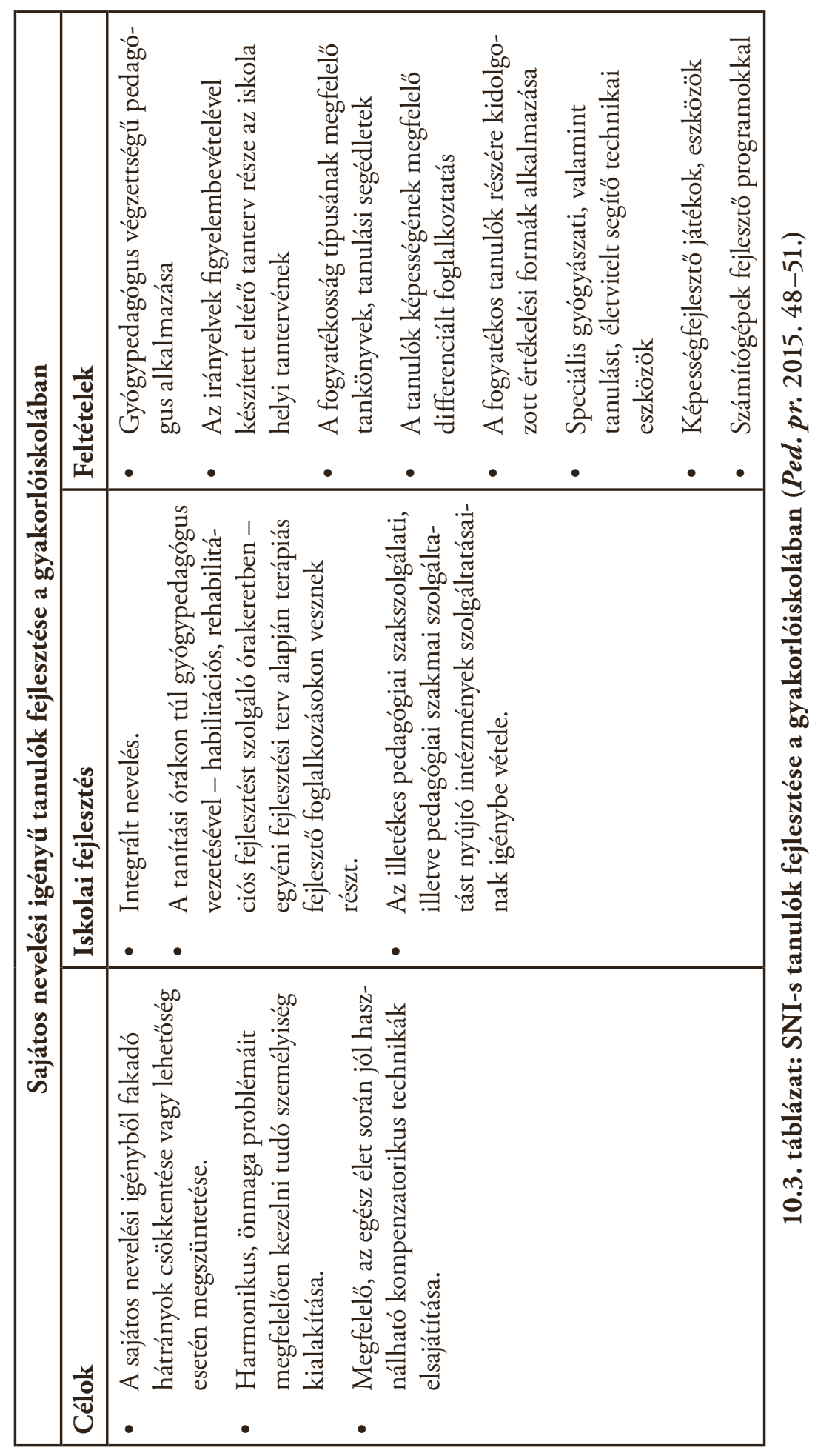


Ahogyan a fentiekben látható (3. táblázat), a sajátos nevelési igényü tanulók fejlesztésére vonatkozóan igen magas színvonalú a gyakorlóiskolában folyó nevelés. Ugyanez mondható el a tehetséges, hátrányos helyzetű, valamint a beilleszkedési és magatartási zavarral küzdő tanulók esetében is. Az alábbi táblázatban (4. táblázat) azon tevékenységeket mutatjuk be, melyeket a gyakorlóiskolában folytatnak a diákok megfelelő fejlődése érdekében.

\begin{tabular}{|c|c|c|c|}
\hline Tevékenységek & 疍 & 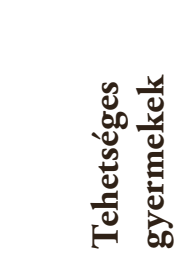 & 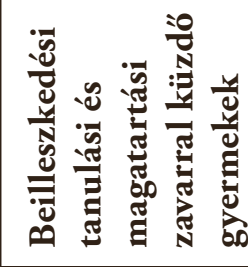 \\
\hline $\begin{array}{l}\text { szoros kapcsolat a helyi } \\
\text { óvodai intézményekkel, } \\
\text { nevelési tanácsadóval, és } \\
\text { gyermekjóléti szolgálattal }\end{array}$ & $\checkmark$ & & $\checkmark$ \\
\hline $\begin{array}{l}\text { az egyéni képességekhez } \\
\text { igazodó tanórai tanulás } \\
\text { megszervezése }\end{array}$ & $\checkmark$ & $\checkmark$ & $\checkmark$ \\
\hline $\begin{array}{l}\text { felzárkóztató órák, fejlesztő } \\
\text { foglalkozások }\end{array}$ & $\checkmark$ & & $\checkmark$ \\
\hline egyéni foglalkozások & $\checkmark$ & $\checkmark$ & $\checkmark$ \\
\hline $\begin{array}{l}\text { képességkibontakoztató } \\
\text { felkészítés és integrációs } \\
\text { felkészítés }\end{array}$ & $\checkmark$ & $\checkmark$ & $\checkmark$ \\
\hline $\begin{array}{l}\text { nevelők és a tanulók } \\
\text { személyes kapcsolatai }\end{array}$ & $\checkmark$ & & $\checkmark$ \\
\hline $\begin{array}{l}\text { az iskolai könyvtár, } \\
\text { valamint az iskola más } \\
\text { létesítményeinek, eszközeinek } \\
\text { egyéni vagy csoportos } \\
\text { használata }\end{array}$ & $\checkmark$ & $\checkmark$ & $\checkmark$ \\
\hline $\begin{array}{l}\text { a középiskolai továbbtanulás } \\
\text { irányítása, segítése }\end{array}$ & $\checkmark$ & $\checkmark$ & $\checkmark$ \\
\hline iskolai sportkör, szakkörök & $\checkmark$ & $\checkmark$ & $\checkmark$ \\
\hline
\end{tabular}




\begin{tabular}{|c|c|c|c|}
\hline Tevékenységek & 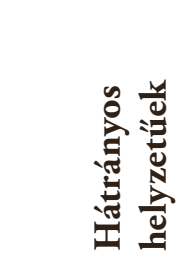 & 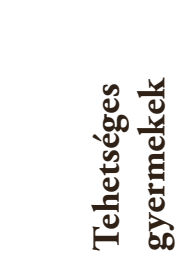 & 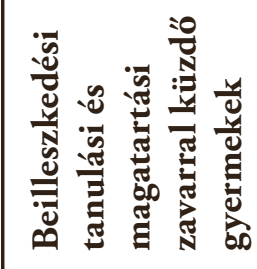 \\
\hline $\begin{array}{l}\text { a tanulók szabadidejének } \\
\text { szervezése (tanórán kívüli } \\
\text { foglalkozások, szabadidőss } \\
\text { tevékenységek, szünidei } \\
\text { programok) }\end{array}$ & $\checkmark$ & $\checkmark$ & $\checkmark$ \\
\hline $\begin{array}{l}\text { szabadidős foglalkozások } \\
\text { (pl. színház- és } \\
\text { múzeumlátogatások) }\end{array}$ & $\checkmark$ & $\checkmark$ & $\checkmark$ \\
\hline $\begin{array}{l}\text { a tanulók szociális } \\
\text { helyzetének javítása }\end{array}$ & $\checkmark$ & & $\checkmark$ \\
\hline $\begin{array}{l}\text { a szülőkkel való } \\
\text { együttmúködés }\end{array}$ & $\checkmark$ & & $\checkmark$ \\
\hline családlátogatások & $\checkmark$ & & $\checkmark$ \\
\hline $\begin{array}{l}\text { szülő́k és a családok nevelési } \\
\text { gondjainak segítése }\end{array}$ & $\checkmark$ & & $\checkmark$ \\
\hline $\begin{array}{l}\text { szülők tájékoztatása } \\
\text { a családsegítő és } \\
\text { a gyermekjóléti } \\
\text { szolgálatokról, } \\
\text { szolgáltatásokról }\end{array}$ & $\checkmark$ & & $\checkmark$ \\
\hline $\begin{array}{l}\text { a tehetséggondozó, fejlesztő } \\
\text { foglalkozások }\end{array}$ & & $\bar{\checkmark}$ & \\
\hline $\begin{array}{l}\text { iskolai és iskolán kívüli } \\
\text { versenyek, vetélkedők, } \\
\text { bemutatók (szaktárgyi, sport, } \\
\text { kulturális stb.) } \\
\end{array}$ & & $\checkmark$ & \\
\hline $\begin{array}{l}\text { a tanulók háromhavonkénti } \\
\text { fejlesztő értékelése a szülőkkel } \\
\text { közösen }\end{array}$ & $\checkmark$ & & \\
\hline
\end{tabular}

10.4. táblázat: Fejlesztő tevékenységek a gyakorlóiskolában (Ped.pr. 2015.

$50-51$. 
A fenti táblázat első ránézésre is azt mutatja meg, hogy rendkívül színes repertoárral rendelkeznek a pedagógusok fejlesztő tevékenységek tekintetében. A pedagógusok kiemelten foglalkoznak az egyéni fejlesztésekkel, feladatként tekintenek a különleges bánásmódot igénylő tanulók teljesítményszintjének növelésére.

A gyakorlóiskola szervezeti és működési szabályzatának áttekintésével még két nagyon fontos dologra kaptunk választ. Egyrészt megtudtuk, hogy a pedagógusok munkaköri leírásában szintén kiemelt helyet foglal el a tehetséggondozás és a felzárkóztatás. Másrészt a hallgatók gyakorlati képzésében is találtunk a témánkhoz kapcsolódó információt, miszerint a gyakorlatvezető tanároknak a nevelési-oktatási gyakorlat alkalmával lehetőséget kell teremteniük a szabadidős tevékenységek, a fejlesztő, tehetséggondozó foglalkozások látogatására. Összességében elmondható, hogy az iskolai dokumentumok alapján a gyakorlóiskola nagy gondot fordít a kiemelt figyelmet igénylő diákok méltányos fejlesztésére. A pedagógiai programban, a szervezeti és működési szabályzatban, valamint a munkatervben is találunk a témára vonatkozó célokat, feladatokat. A továbbiakban érdekes lesz azt megvizsgálnunk, hogy a fenti dokumentumokban leírtak és a pedagógusok nézetei, vagyis a megvalósulás milyen összhangban vannak egymással. Az ezekre vonatkozó empirikus adatokat a következő fejezetben láthatjuk. Képet kapunk arról, hogy a pedagógusok milyen módon valósítják meg a kiemelt figyelmet igénylő tanulók fejlesztését (5. táblázat), valamint a 10.2.3. fejezetben részletesen taglaljuk a pedagógusok által kitűzött célok és azok tényleges megvalósulása terén megfigyelhetö összefüggéseket.

\subsection{Pedagógusok nézetei a kiemelt figyelmet igénylő tanulók fejlesztésének meg- valósulásáról}

Ennél a kérdéskörnél elsősorban arra kerestük a választ, hogy a gyakorlóiskola mindennapi tevékenysége során hogyan jelenik meg a kiemelt figyelmet igénylő tanulók fejlesztése. A pedagógusok hogyan valósitják meg a felzárkóztatást, tehetséggondozást, mit gondolnak a téma fontosságáról? Milyen módszereket használnak a tanulók fejlesztésének érdekében? Mennyire tartják szükségesnek az e területeken való továbbképzéseket? Ez összhangban van-e az intézményi elvárásokkal? Vannak-e összefüggések az egyéni képességekhez való alkalmazkodás szükségességének megitélése, valamint ennek a tanórai megvalósulása között? Kutatásunkban először szerettük volna megvizsgálni, hogy a különleges bánásmódot igénylö gyermekek fejlesztése milyen módokon valósul meg a gyakorlóiskolában. (2. sz. Tanári kérdöiv/18.) Összesen 113 pedagógus adott választ kérdésünkre. A válaszokból megítélhető, hogy a tanárok többféleképpen nyújtanak segítséget tanítványaiknak, ami igazolja felkészültségüket az egyéni bánásmóddal kapcsolatos ismereteikkel kapcsolatban. 


\begin{tabular}{|c|c|c|c|c|c|c|c|}
\hline \multirow[b]{2}{*}{ Kategóriák } & \multicolumn{7}{|c|}{$\begin{array}{l}\text { Kiemelt figyelmet igénylő tanulók fejlesztése } \\
N=113\end{array}$} \\
\hline & 宽 & 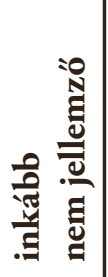 & 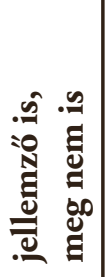 & 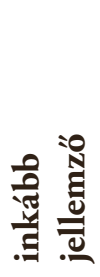 & 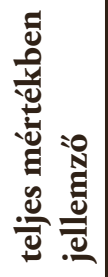 & 琎 & 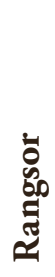 \\
\hline $\begin{array}{l}\text { Egyéni fejlesztési terveket } \\
\text { készítek. }\end{array}$ & 4 & 21 & 42 & 37 & 9 & 3,23 & 6. \\
\hline $\begin{array}{l}\text { Személyre szabott } \\
\text { követelményeket állítok } \\
\text { tanulóim elé. }\end{array}$ & 0 & 5 & 37 & 49 & 22 & 3,78 & 3. \\
\hline $\begin{array}{l}\text { Minden tanulóval közösen } \\
\text { határozom meg a fejlesztési } \\
\text { célokat. }\end{array}$ & 3 & 14 & 45 & 43 & 8 & 3,35 & 5. \\
\hline $\begin{array}{l}\text { A tanórákon csoportmunka } \\
\text { esetén különböző nehézségü } \\
\text { feladatokat adok a diákoknak. }\end{array}$ & 0 & 4 & 29 & 54 & 26 & 3,90 & 2. \\
\hline $\begin{array}{l}\text { Egyéni feladatokat adok } \\
\text { a tanulóknak az órákon. }\end{array}$ & 2 & 6 & 43 & 49 & 13 & 3,58 & 4. \\
\hline $\begin{array}{l}\text { Minden diákot a saját } \\
\text { képességeihez mérten, } \\
\text { differenciáltan értékelek. }\end{array}$ & 1 & 3 & 27 & 45 & 37 & 4,01 & 1. \\
\hline
\end{tabular}

10.5. táblázat: A kiemelt figyelmet igénylő tanulók fejlesztésének módjai

Az egyéni bánásmód egyik lehetséges módja, hogy egyéni fejlesztési terveket készítenek a pedagógusok diákjaik számára. Az eredmények szerint ez változó képet mutat a gyakorlóiskolában. Vannak olyanok, akik felhasználják munkájuk során a diákok fejlesztése érdekében a tervkészítést, de többen jelölték válaszként a nem jellemző kategóriákat is. A pedagógusok több mint 62,9\%-a személyre szabott követelményeket állít a tanulók elé, ami jelentősnek mondható. Többen közösen határozzák meg tanulóikkal a fejlesztési célokat, de láthatjuk a táblázatban, hogy ez a szám nem éri el összesen a válaszok 50\%-át. A tanórákon megjelenő csoportmunka esetén a pedagógusok jórészt különböző nehézségű feladatokat adnak diákjaik számára, ami segíti őket az egyéni fejlődésükben, a tanórán megjelenő más munkaformáknál is igyekeznek egyéni feladatot adni, bár ez a szám jóval kevesebb, mint a csoportmunkánál. A pedagógusok válaszai alapján láthatjuk, hogy az egyéni bánásmód 
egyik legkiemelkedőbb lehetőségének tartják a csoportmunka közben lévő egyénre szabott feladatokat. A legmagasabb eredmény azonban az értékelés módjában látható. A tanárok nagy része fontosnak ítélte meg az egyéni képességekhez igazodó, differenciált értékelést, ami arra ad számunkra választ, hogy a gyakorlóiskolában nagy figyelmet fordítanak a differenciálásra, főként a diákok egyéni képességeihez igazodó értékelésre. Kevésbé ítélik fontosnak az egyéni feladatokat a tanórákon, a tanulókkal való közös fejlesztési célok meghatározását és az egyéni fejlesztési tervek elkészítését. Érdemes lenne átgondolni ezeket az egyéni bánásmód tényleges, még magasabb színvonalon történő megvalósulása érdekében. Egy szakmai fejlesztő iskolában kiemelten fontos, hogy megfelelő módszereket, eljárásokat alkalmazzanak a pedagógusok a tanulók méltányos fejlesztésére.

Arra kérdésre, hogy „Mennyire tartják fontosnak a tanulók egyéni tanulási képességeikhez, adottságaikhoz való alkalmazkodást?”, a következő válaszokat kaptuk. (2. sz. Tanári kérdöiv/6.)

\begin{tabular}{|l|c|c|}
\hline $\begin{array}{l}\text { Egyéni képességekhez való } \\
\text { alkalmazkodás fontossága }\end{array}$ & Gyakoriság (fo) & $\begin{array}{c}\text { Százalékos } \\
\text { gyakoriság (\%) }\end{array}$ \\
\hline egyáltalán nem tartom fontosnak & 0 & 0 \\
\hline inkább nem tartom fontosnak & 0 & 0 \\
\hline fontosnak is tartom, meg nem is & 40 & 1,8 \\
\hline inkább fontosnak tartom & 71 & 35,4 \\
\hline nagyon fontosnak tartom & 113 & 62,8 \\
\hline Összesen & 2 & 100,0 \\
\hline
\end{tabular}

10.6. táblázat: A pedagógusok megítélése az egyéni képességekhez való alkalmazkodásról

Összesen 113 értékelhető válasz érkezett kérdésünkre (6. táblázat). Az eredmények azt mutatják, hogy a pedagógusok nagy része úgy ítéli meg, az egyéni képességekhez való alkalmazkodás rendkívül jelentős tényező a tanítási-tanulási folyamatban. A fenti értékekből kiolvashatjuk, hogy a tanárok 98,2\%-a tartja fontosnak, és egyáltalán nem fordult elö olyan, aki a „nem tartom fontosnak” lehetőségek közül jelölte volna válaszát. Vizsgálataink alapján elmondhatjuk, hogy a pedagógusok úgy vélik, az egyéni képességekhez való alkalmazkodás egy fontos feladat. Az előző adatainkból az is bebizonyosodott, hogy kevesebb mint 50\%-uk az, aki egyéni fejlesztési tervet készít, vagy egyéni feladatot ad diákjainak az órán.

A „Tart Ön korrepetálást, fejlesztö foglalkozást az iskolában?” kérdésünkre $(2$ sz. Tanári kérdöiv/9.) 69\%-ban jelöltek igen választ, ami igen magas számnak tekinthető. Ebből is 
látszik, hogy a gyakorlóiskolában nagy hangsúlyt fektetnek a lemaradók felzárkóztatására. A tanárok kiemelkedő módszertani felkészültségéről árulkodik, hogy rendkívül színes repertoárral rendelkeznek a fejlesztő foglalkozásokon használt technikák tekintetében. Az alábbiakban kiemeltem néhányat a tanárok által a tanulók fejlesztésére legtöbbet használt módszerek, munkaformák, feladatok közül. Megpróbáltam összegyűjteni azokat a technikákat, melyeket a pedagógusok $(\mathrm{N}=113)$ a legnagyobb számban említettek válaszaikban: egyéni foglalkozás (38), differenciálás (26), differenciált csoportmunka (13). Attól azonban nem tekinthetünk el, hogy a módszerek sokaságát említették válaszaikban a gyakorlóiskolai tanárok. A fentieken kívül, a teljesség igény nélkül még felsorolunk néhányat: felzárkóztatás, tanulópárok, gyakorlás, tanulásmódszertani segítségnyújtás, magyarázat, lehetőség későbbi bemutatásra, korrepetálás stb.

A felzárkóztatáson kívül érdekelt bennünket az is, hogy vajon a tehetséges gyermekek esetében milyen tevékenységi formákat használnak a pedagógusok (2. sz. Tanári kérdöiv/10.). A kérdésünkre kapott válaszok ( $\mathrm{N}=113)$ alapján itt is összegyüjtöttük a legnagyobb számban előforduló módszereket, melyek a következők voltak: versenyre való felkészítés (35), egyéni foglalkozás (28), differenciálás (27). Elmondhatjuk azonban azt is, hogy rendkívül színes repertoárral rendelkeznek a pedagógusok a tehetséggondozásra használt módszereikben, hiszen alkalmaznak még kooperatív technikákat, kutatómunkát/önálló ismeretszerzést, többletfeladatokat, projektmunkát, kiselőadásokat, élménypedagógiát stb.

Következtetésként leszűrhető, hogy a gyakorlóiskola tanárai változatos módszertani repertoárt használva fejlesztik mind a felzárkóztatásra szoruló, mind pedig a tehetséges gyermekeket. Vannak olyan módszerek, melyek mindkét esetben megjelennek, és természetesen találkozunk eltérő tevékenységekkel is. Összességében megfogalmazhatjuk, hogy nagy hangsúlyt helyeznek a tudatos fejlesztésre, amely egy szakmai fejlesztő iskolánál is rendkívül fontos, hiszen a változatos módszertani repertoár alkalmazása segíti a tanulók különbözőségeinek kezelését is.

Arra kérdésre, hogy „Ön szerint melyek lehetnek a gyakorlóiskola legfontosabb feladatai?”, (3. sz. Tanári kérdöív/1) 102 pedagógus válaszolt. Az egyéni fejlődés szempontjából kiemelt fontosságúak a táblázatunkban (7. táblázat) az alábbi kategóriák voltak: 


\begin{tabular}{|c|c|c|c|c|c|}
\hline Kategóriák & 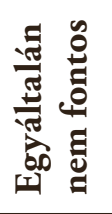 & 泀 & 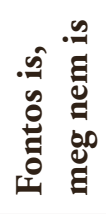 & $\stackrel{0}{\stackrel{0}{0}}$ & 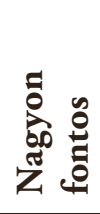 \\
\hline $\mathrm{N}=102$ & $\%$ & $\%$ & $\%$ & $\%$ & $\%$ \\
\hline $\begin{array}{l}\text { Minél sokszínúbb szabadidős } \\
\text { tevékenységrendszer felkínálása }\end{array}$ & 0 & 3,9 & 24,5 & 49,0 & 22,5 \\
\hline Tanulmányi versenyeken való részvétel & 0 & 1,0 & 16,7 & 44,1 & 38,2 \\
\hline A lemaradó tanulók felzárkóztatása & 0 & 0 & 2,0 & 42,2 & 55,9 \\
\hline
\end{tabular}

10.7. táblázat: Iskolai tevékenységek és egyéni fejlődés

A fenti táblázatban (7. táblázat) láthatjuk, hogy a pedagógusok fontosnak tartják a minél sokszínűbb szabadidős tevékenységek felkínálását, beleértve ezekbe a szakköröket, kirándulásokat, versenyeket stb. A különféle szabadidős tevékenységek nagyban hozzájárulnak az egyéni fejlődéshez is. A tanulmányi versenyeken való részvételt a tanárok több mint 82,3\%-a ítélte fontosnak. A lemaradó tanulók felzárkóztatása került az első helyre, hiszen ahogyan azt a fentiekben olvashattuk rengetegféle módszert alkalmaznak felzárkóztatásra, és ezek az eredmények is arról árulkodnak, hogy kiemelt szerepet játszik a gyakorlóiskolában a tanulók egyéni fejlesztése.

A következő kérdéseinkre: „Jelenleg mely területeken tartja a leginkább szükségesnek a saját szakmai fejlödését?” (3. sz. Tanári kérdöiv/5), valamint „Véleménye szerint az iskola mely területeken tartja a legfontosabbnak a pedagógusai szakmai fejlödését?”, (3. sz. Tanári kérdöiv/3.) témánk szempontjából a 2. ábra mutatja meg a választ.

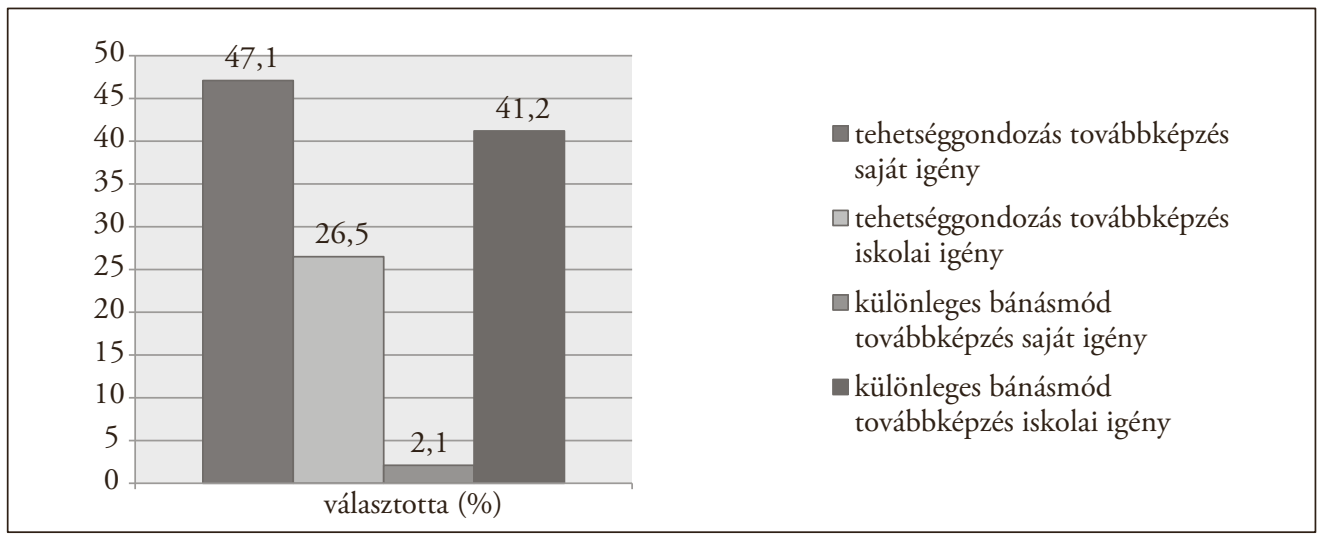

10.2. ábra: A pedagógusok saját és az iskola által elvárt továbbképzési lehetőségei 
A 2. ábra adataiból láthatjuk mind a tehetséggondozás, mind pedig a felzárkóztatás tekintetében nagy eltérés tapasztalható az intézményi és az egyéni igények között. Ebből azt a konzekvenciát vonhatjuk le, hogy a pedagógusoknak nagyobb igénye lenne a saját maguk által megválasztott képzéseken való részvételre, hiszen ők teljesen mást ítélnek fontosnak. Ez azért is lenne nagyon jelentős, mert ők a mindennapi gyakorlatban talán jobban átlátják azokat a területeket, amelyek javítást igényelnének, és amelyben szükséges lenne a saját fejlődésük.

Összefüggést kerestünk arra vonatkozóan, hogy vajon azok a pedagógusok, akik fejlődni szeretnének a tehetséggondozás, valamint a különleges bánásmódot igénylő gyermekekkel kapcsolatos tudásuk területén, fontosnak ítélik-e meg az egyéni képességekhez való alkalmazkodást is.

\begin{tabular}{|c|c|c|c|c|}
\hline & & $\begin{array}{c}\text { Inkább } \\
\text { fontosnak } \\
\text { tartom }\end{array}$ & $\begin{array}{c}\text { Nagyon } \\
\text { fontosnak } \\
\text { tartom }\end{array}$ & Összesen \\
\hline Kategóriák & Választás & $\begin{array}{c}\text { Gyakoriság } \\
\text { (fö) }\end{array}$ & $\begin{array}{c}\text { Gyakoriság } \\
\text { (fö) }\end{array}$ & $\begin{array}{c}\text { Gyakoriság } \\
\text { (fo) }\end{array}$ \\
\hline Tehetséggondozás & igen & 6 & 19 & 25 \\
\hline $\begin{array}{l}\text { Különleges bánásmó- } \\
\text { dot ig. tan. fejlődésének } \\
\text { támogatása }\end{array}$ & igen & 12 & 26 & 38 \\
\hline
\end{tabular}

10.8. táblázat: Továbbképzések és egyéni képességekhez való alkalmazkodás összefüggése

A táblázatból világosan látszik (8. táblázat), hogy azok a válaszadók, akik e két területet választották, egyetértenek abban, hogy az egyéni képességekhez való alkalmazkodás kiemelt fontosságú. Következtetésként elmondhatjuk, hogy összefüggés van a tehetséggondozást és különleges bánásmódot igénylő gyermekek fejlődésének támogatását előtérbe helyezők és az egyéni képességekhez való alkalmazkodást fontosnak ítélők válaszai között.

A következő kérdésekben: „Mennyire tartja fontosnak az adott célok megvalósitását a tanulók kompetenciáinak fejlesztésében?” (2. sz. Tanári kérdöiv/6.), valamint „Ön milyen gyakran alkalmazza az adott megközelítést saját gyakorlatában” (2. sz. Tanári kérdöiv/7.), összefüggést kerestünk az egyéni képességekhez való alkalmazkodás, valamint annak gyakorlati megvalósítása között. 


\begin{tabular}{|c|c|c|c|c|c|}
\hline $\begin{array}{l}\text { Egyéni képes- } \\
\text { ségekhez való }\end{array}$ & $\begin{array}{l}\text { egyáltalán } \\
\text { nem fontos }\end{array}$ & $\begin{array}{c}\text { inkább } \\
\text { nem fontos }\end{array}$ & $\begin{array}{l}\text { fontos is, } \\
\text { meg nem } \\
\text { is }\end{array}$ & $\begin{array}{c}\text { inkább } \\
\text { fontos }\end{array}$ & $\begin{array}{l}\text { nagyon } \\
\text { fontos }\end{array}$ \\
\hline $\begin{array}{l}\text { alkalmazkodás } \\
\mathrm{N}=94\end{array}$ & $\begin{array}{c}\text { Gyakoriság } \\
\text { (fö) }\end{array}$ & $\begin{array}{c}\text { Gyakoriság } \\
\text { (fö) }\end{array}$ & $\begin{array}{c}\text { Gyakoriság } \\
\text { (fö) }\end{array}$ & $\begin{array}{c}\text { Gyakoriság } \\
\text { (fö) }\end{array}$ & $\begin{array}{c}\text { Gyakoriság } \\
\text { (fö) }\end{array}$ \\
\hline az óráim felén & 0 & 0 & 1 & 4 & 12 \\
\hline $\begin{array}{l}\text { az óráim több } \\
\text { mint felén }\end{array}$ & 0 & 0 & 1 & 18 & 21 \\
\hline minden órámon & 0 & 0 & 0 & 13 & 24 \\
\hline
\end{tabular}

10.9. táblázat: Az egyéni képességekhez való alkalmazkodás és a megvalósulás

A fenti számadatokból megállapítható (9. táblázat), hogy a pedagógusok nemcsak fontosnak ítélik meg saját munkájukban az egyéni tanulási képességekhez, adottságokhoz való alkalmazkodást, de az óráik legalább felén legtöbbjük alkalmaz olyan módszereket, technikákat, differenciálást stb., amellyel hozzásegíti tanulóit fejlődésükhöz. Szinte teljes egyetértésben fontosnak tartották az egyéni képességekhez való alkalmazkodást, és válaszaikban leírták, hogy az óráikon jórészt alkalmazzák is azt. Az eredmények alapján kijelenthetjük, hogy szoros összefüggés van a kettő között, hiszen nem csupán elméletben fontos számukra, hanem a gyakorlatban is igyekeznek megvalósítani az egyéni szintekhez alkalmazkodó tanítást.

\subsection{Az iskolai dokumentumok és a pedagógusok véleményének összehasonlítása}

Ebben a fejezetben megpróbálunk választ keresni arra a kérdésre vonatkozóan, hogy az iskolai dokumentumokban megfogalmazott célok és a pedagógusok által adott válaszok mennyire állnak egymással összhangban.

Elsőként azt vizsgáljuk meg, hogy a tehetséggondozás és a felzárkóztatás hogyan jelenik meg az egyes dokumentumokban, és ezzel összefüggésben a pedagógusok nézetei hasonló adatokkal szolgálnak-e.

Az intézmény munkatervében azt találtuk, hogy összesen 156-féle versenyen való részvételt tűztek ki maguk elé a pedagógusok, valamint a pedagógiai programban leírtak szerint a gyakorlóiskola tanárainak kötelessége megszervezni a tehetséges tanulók egyéni fejlesztését, különféle versenyekre való felkészítését. Ezek az adatok összevethetők azzal, hogy a pedagógusok nagy százaléka nyilatkozott arról, hogy tart valamilyen fejlesztő foglalkozást, korrepetálást az iskolában. 


\begin{tabular}{|c|c|c|}
\hline $\begin{array}{c}\text { Fejlesztő foglalkozást } \\
\text { tart }\end{array}$ & $\begin{array}{c}\text { Gyakoriság } \\
\text { (fö) }\end{array}$ & $\begin{array}{c}\text { Százalékos gyakoriság } \\
\text { (\%) }\end{array}$ \\
\cline { 1 - 1 } nem & 35 & 31,0 \\
igen & 78 & 69,0 \\
\cline { 1 - 1 } Összesen & 113 & 100,0 \\
\hline
\end{tabular}

10.10. táblázat: A fejlesztő foglalkoztatást tartó tanárok száma

26. Részt veszel az iskolában korrepetálásokon, fejlesztő órákon?

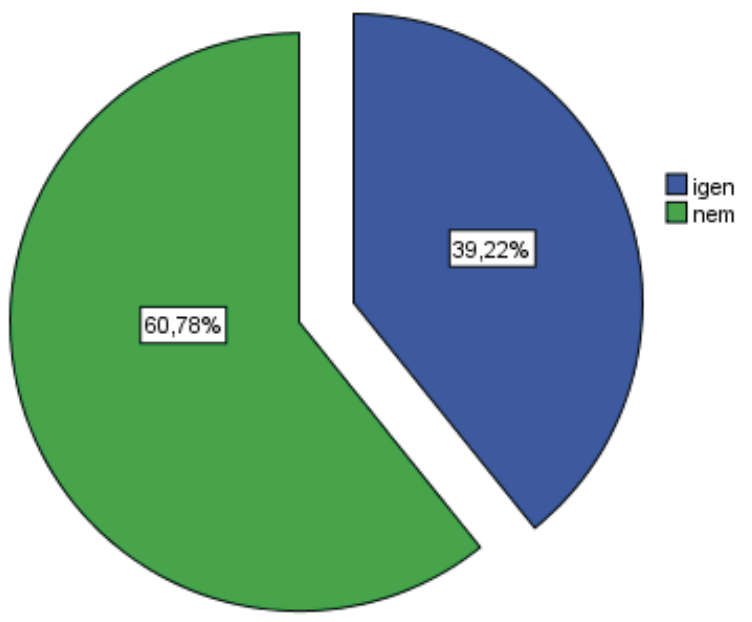

10.3. ábra: Korrepetálásokon, fejlesztő órákon való részvételi arány

A 10. táblázat adatai alapján elmondható, hogy a pedagógusok igen magas százalékban, 69\%-ban válaszoltak igennel a feltett kérdésre, miszerint tartanak valamilyen fejlesztő foglalkozást, korrepetálást az intézményben. Ez összefüggésben van azzal, amit a dokumentumokban találtunk, hiszen a rengeteg versenyre való felkészítéshez és a tanulásban lemaradók felzárkóztatásához igen nagy szükség van egyéni órák megtartására. A tanulók közel 40\%-a vesz részt valamilyen korrepetáláson, fejlesztő foglalkozáson (3. ábra).

A fejlesztő órákon kívül természetesen a pedagógusok igyekeznek tanórai kereteken belül is megvalósítani a tanulók egyéni fejlesztését. Ahogyan az előző fejezetünkben láthattuk, a pedagógusok nagyon sokszínủen próbálják a tanulók teljesítményét növelni, különös tekintettel a kiemelt figyelmet igénylő diákokra. Ez szintén összefüggést mutat azzal, amit az iskolai dokumentumokban találunk.

Végül összevethetjük a pedagógiai programban leírtakat azzal, hogy a gyakorlóiskolai tanárok az óráiknak hányad részében érzik megvalósultnak az egyéni képességekhez való alkalmazkodást. A 9. táblázatban megállapítottuk, hogy a pedagógusok több mint 
90\%-a legalább az óráinak a felén megpróbálja egyéni bánásmódban részesíteni tanulóit és megtenni mindent annak érdekében, hogy képességeikhez mérten a számukra leginkább kedvező módon sajátíthassák el a tananyagot. A pedagógiai programban azt olvashatjuk, hogy az egyéni képességekhez igazodó tanórai tanulás megszervezése a kiemelt figyelmet igénylő tanulók minden egyes csoportjánál megjelenik (2. táblázat). Ennél fogva kijelenthetjük, hogy a pedagógusok által célkitűzésként megfogalmazott egyéni képességfejlesztésre vonatkozó feladatok összhangban állnak a tanórai megvalósulással.

Mindent összevetve azt a következtetést vonhatjuk le, hogy a gyakorlóiskola által elkészített dokumentumokban lévő célokat és feladatokat a pedagógusok igyekeznek megvalósítani s ez által a kiemelt figyelmet igénylő tanulókat a lehető legmagasabb szintre fejleszteni.

\subsection{Tehetséggondozás és felzárkóztatás a gyakorlóiskolában}

Kutatásunkban kiemelt jelentőségünek tartottuk megvizsgálni, hogy a tanulók hogyan ítélik meg a gyakorlóiskolában a kiemelt figyelmet igénylő gyermekek fejlesztését. Törekedtünk választ kapni arra a kérdésre, hogy az egyéni bánásmódban való részesülés hogyan jelenik meg a diákok véleményeiben, és megvizsgáltuk, hogy eltérő képet kapunk-e a tanárok és diákok szemszögéből a témánk szempontjából adott kérdéskörre.

Kérdésünkre - „Kérjük, gondold végig, hogy a gyakorlóiskolai tanórákra általában mennyire jellemzöek az alábbi állitások!" (Felsös tanulói kérdöiv/8.) - az alábbi táblázat adatai (11. táblázat) ad nak választ.

\begin{tabular}{|c|c|c|c|c|c|}
\hline \multirow{2}{*}{$\begin{array}{l}\text { Kategóriák } \\
\mathrm{N}=255\end{array}$} & 宽 & 苞 & 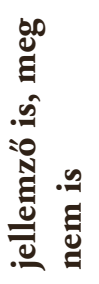 & 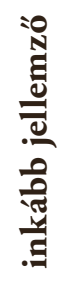 & 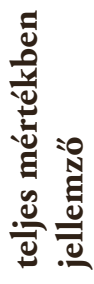 \\
\hline & \multicolumn{5}{|c|}{ Gyakoriság (fó) } \\
\hline $\begin{array}{l}\text { A tanárok segítik a tehetsé- } \\
\text { ges gyerekeket. }\end{array}$ & 4 & 11 & 57 & 93 & 90 \\
\hline $\begin{array}{l}\text { A tanárok segítenek, ha } \\
\text { elakadok a tanulásban. }\end{array}$ & 18 & 24 & 79 & 77 & 57 \\
\hline $\begin{array}{l}\text { Segítséget kapok tanáraim- } \\
\text { tól, hogy jobb tanulmányi } \\
\text { eredményt érjek el. }\end{array}$ & 17 & 23 & 75 & 80 & 60 \\
\hline
\end{tabular}

10.11. táblázat: Tanári segítségnyújtás a tanulók számára 
A tehetséges tanulók tekintetében következtetésként elmondhatjuk, hogy a tanulók többsége úgy ítéli meg, megfelelő segítséget nyújtanak a tanárok számukra, tehetségük kibontakoztatására. A tanulók több mint 70\%-a válaszolta azt, hogy jellemző tanáraikra a tehetséges tanulók segítése, és csak kevesen választották a „nem jellemző” kategóriákat. A tanulásban történő segítés már nem ennyire egyértelmű képet mutat. A tanulók 52,6\%-a érzi úgy, hogy tanárai segítenek neki, ha elakad a tanulásban. Legtöbben a „jellemző is, meg nem is" kategóriát jelölték válaszként. A tanulóknak való segítségnyújtás a jobb tanulmányi eredmény érdekében hasonló képet mutat az előzőekben említett tanulásban elakadók segítéséhez. A tanulók 54,9\%-a jelölte válaszként, hogy a pedagógusok segítenek neki a jobb tanulmányi eredmény elérése érdekében. Itt szintén erőteljesebben jelent meg a „jellemző is, meg nem is” köztes kategória megjelölése, mint a tehetséggondozás területén. Összességében elmondhatjuk, hogy a gyakorlós tanárok diákjaik megítélése szerint is igyekeznek őket egyéni bánásmódban részesíteni, segíteni őket a tanulásban, hiszen kevesen voltak azok, akik ezt egyáltalán nem tartották jellemzőnek. Leginkább a tehetséggondozás területén mondható jelentősnek a kiemelt figyelmet igénylő gyermekek fejlesztése. A tanulásban való segítségnyújtásra azonban nagyobb mértékben tartanának igényt a gyakorlós diákok. Lehetséges, hogy azok a diákok is, akik nem szorulnak egyébként felzárkóztatásra, mégis szükségét éreznék a nagyobb odafigyelésnek ezen a téren. Az alábbi táblázat szintén a tehetséggondozás magas színvonalát látszik igazolni. Megfigyelhetjük, hogy a tanulók nagy százaléka jár versenyekre a gyakorlóból. (Felsős tanulói kérdöiv/15.)

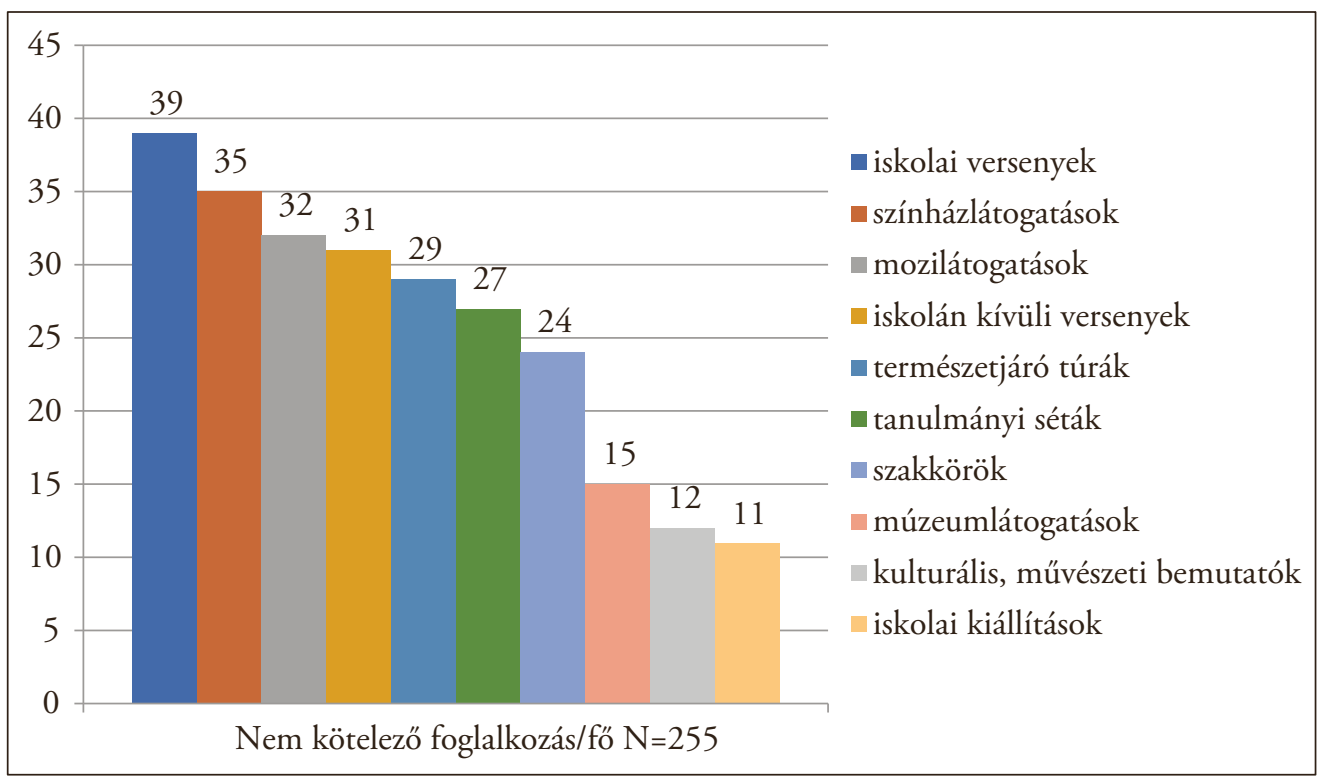

10.4. ábra: A diákok nem kötelező iskolai programokon való részvételi aránya 
A nem kötelező iskolai programokon való részvételnél a legtöbben az iskolai versenyeken való részvételt jelölték meg (4. ábra), de nem sokkal kevesebben vettek már részt más, az iskolán kívüli versenyeken is. Ezekből az eredményekből következtethetünk arra, hogy a gyakorlóban tanító pedagógusok valóban nagy figyelmet fordítanak a tehetségek fejlesztésére. Ezek az eredmények összefüggésben állnak a pedagógusoktól kapott válaszokkal a tehetséggondozást illetően. A „Pedagógusok nézetei a kiemelt figyelmet igénylő tanulók fejlesztésének megvalósulásáról” címü fejezetben olvashatunk a pedagógusok által a tehetségek kibontakoztatására használt módszerekről, valamint arról is, hogy fontosnak ítélnének meg a témával kapcsolatos továbbképzéseket is. Következtetésként elmondhatjuk, hogy a tanulók megítélése szerint magas színvonalon folyik a gyakorlóiskolában a tehetséggondozás, s ez összhangban van a pedagógusok véleményével, mely szerint ők is fontosnak tartják az e területen való fejlesztést és saját fejlődésüket is.

Arra a kérdésre, hogy „Szerinted miért fejlödtél?” (Felsős tanulói kérdöiv/25.) a jobb tanulmány elérése érdekében, a diákok a következő ábrán látható válaszokat adták:

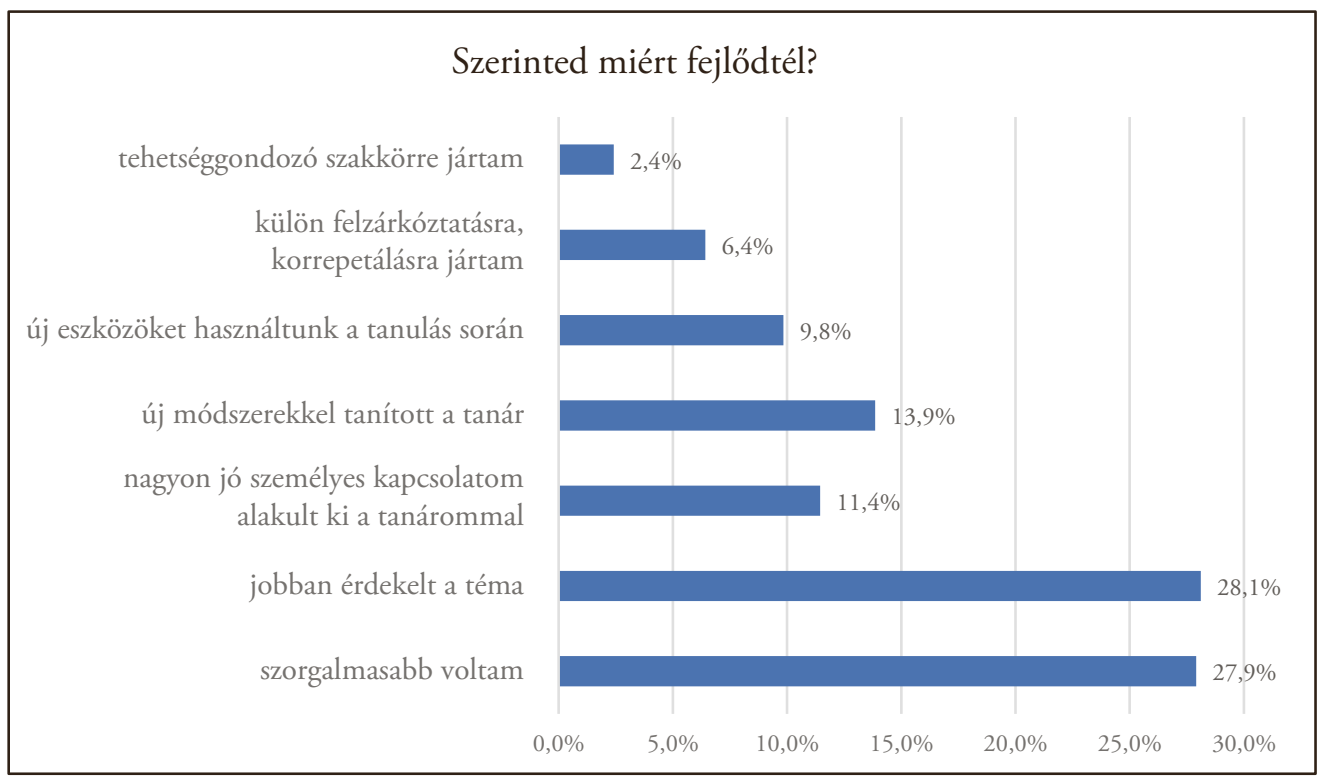

10.5. ábra: A tanulók fejlődésének okai

Az 5. ábráról leolvasható, hogy a tanulók többsége a téma vonzerejének köszönhetően érzi úgy, hogy fejlődött, és nagyon sok diák szerint a szorgalmuk játszott kiemelkedő szerepet a jobb teljesítmény elérésben. Ami témánk szempontjából érdekes és tanulságos lehet, az a tehetséggondozó szakkörök és a felzárkóztató foglalkozások alacsony választásának száma. A diákok túlnyomó része ezt a két területet érzi legkevésbé befolyásoló tényezőnek 
fejlődése szempontjából. Úgy érzik, ezek a szempontok nem játszanak olyan fontos szerepet a jobb tanulmányi eredmények elérésénél. Érdekes meglátni azt az ellentmondást, hogy a tanárok és diákok véleménye szerint is jól működik a gyakorlóban a tehetséggondozás és a felzárkóztatás, mégis nagyon csekély mértékben tulajdonítanak ezeknek jelentőséget fejlődésük szempontjából. Mi lehet ennek az oka?

Az alábbi ábrán a rendszeresen versenyre járók részvételi arányát figyelhetjük meg.

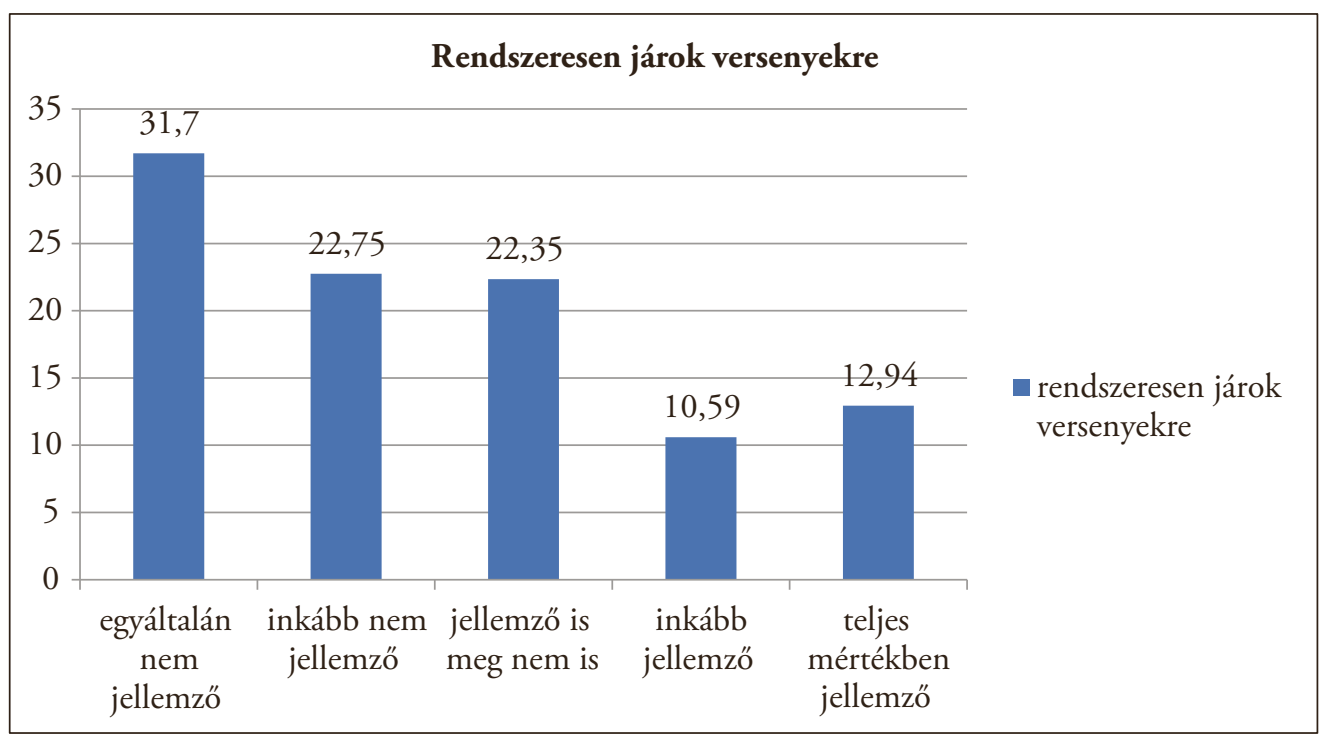

10.6. ábra: A diákok versenyeken való részvételi aránya

Talán ez a diagram (6.ábra) magyarázatul szolgálhat az előző eredményekre, hiszen ahogyan láthatjuk, a diákoknak csupán egy rétege jár rendszeresen versenyekre, ami azt bizonyítja, hogy természetesen a gyakorlóiskolában nem minden tanuló kiemelten tehetséges gyermek. Ahogyan azt a szakirodalmi bevezetőben olvashattuk, egy szakmai fejlesztő iskolának tükröznie kell a társadalom sokszínűségét, így nem is lenne észszerủ, ha csupán jó képességű tanulókból tevődne össze a gyakorlóiskolába járó diákok csoportja. A tanulók körülbelül 22\%-a írta az „inkább jellemző” és „teljes mértékben jellemző” válaszlehetőségek valamelyikét, ami így is magas aránynak mondható. Az adatok azt mutatják, hogy a tanulók $22 \%$-a vesz részt rendszeresen versenyeken. A 4. ábrán pedig láthattuk, hogy azok aránya, akik már legalább egyszer részt vettek valamilyen versenyen, még magasabb.

Összességében elmondhatjuk, hogy a tanárok igyekeznek minél több lehetőséget biztosítani a tanulók számára a versenyeken való részvételre és felkészítésükre, $s$ ezzel a diákok is egyetértenek, mégsem tekintik mérvadónak a tehetséggondozó szakköröket fejlődésük szempontjából. A felzárkóztatással valószínűleg hasonlóképpen 
gondolkodhatunk, hiszen nem minden tanuló szorul felzárkóztatásra. Ez lehet az oka annak, hogy alacsonyabb számban jelölték a tanulók válaszként.

Arra kérdésre, hogy a tanulók milyen véleménnyel rendelkeznek a következő állításról: "A tanórákon gyakran van lehetöségem, hogy személyre szabott feladatokat oldjak meg.", a 7. ábrán láthatjuk a válaszokat.

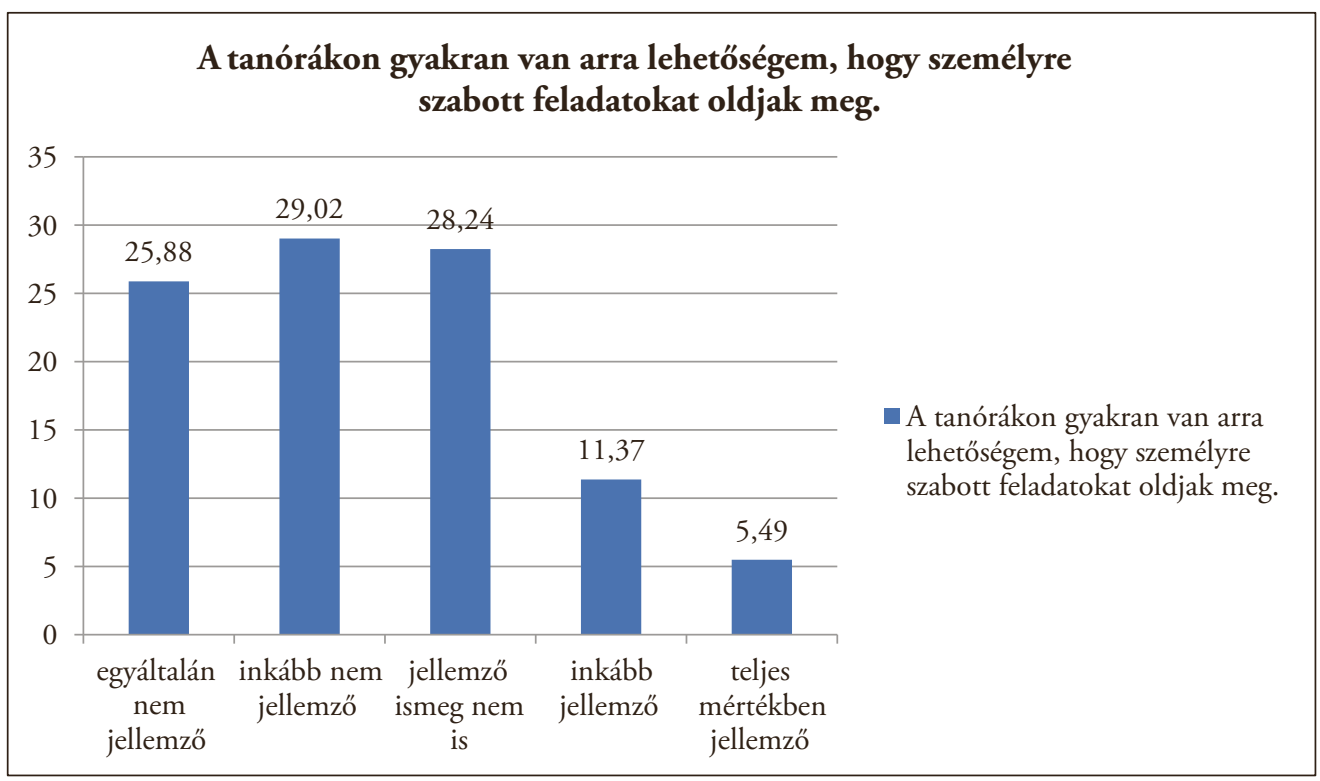

10.7. ábra: A diákok véleménye a tanórán lévő személyre szabott feladatokról

Az eredmények arról árulkodnak, hogy a gyakorlós diákok nagy része nem tartja jellemzőnek a személyre szabott feladatokat a tanórákon. Csak kevés olyan diák van, aki teljes mértékben úgy érzi, saját maga számára összeállított feladatokat oldhat meg a tanórákon.

Érdekes összevetni ezt az eredményt a pedagógusok által adott válaszokkal. Az alábbi adatokat a 5. táblázatból emeltem ki (12. táblázat). Látható, hogy a pedagógusok hasonlóképpen vélekednek az egyéni, személyre szabott feladatok tekintetében a diákokkal. Mindkét csoport véleménye alapján elmondható, hogy ez a terület még némi fejlődést kíván.

\begin{tabular}{|l|l|l|}
\hline \multirow{2}{*}{$\begin{array}{l}\text { Egyéni feladatokat adok } \\
\text { a tanulóknak az órákon. }\end{array}$} & \multicolumn{2}{|l|}{ Teljes mértékben jellemző } \\
\cline { 2 - 3 } & Gyakoriság (fö) & Százalékos gyakoriság (\%) \\
\cline { 2 - 3 } & 13 & 11,5 \\
\hline
\end{tabular}

10.12. táblázat: Egyéni feladatok a tanórákon 
Összevetve a pedagógusok véleményét a diákokéval a tehetséggondozás és felzárkóztatás, valamint az egyéni bánásmód tekintetében, elmondható, hogy a tanulók megítélései hasonló képet mutatnak tanáraikéhoz. Alapvetően megfelelőnek érzik az iskola által nyújtott lehetőségeket a kiemelt figyelmet igénylő tanulók tekintetében, azonban válaszaikból kiolvasható a személyre szabott feladatok hiánya.

Érdekesnek tartottuk megvizsgálni az egyetemi hallgatók véleményét is a gyakorlóiskola és az egyetemi képzés közötti összhangról. Kíváncsiak voltunk arra, hogy témánk szempontjából mennyire érzik magukat felkészültnek a hallgatók. Az egyetem és a gyakorló vajon megfelelően készíti fel őket a kiemelt figyelmet igénylő tanulók nevelésére?

Arra kérdésre, hogy „Milyen mértékben biztositja a gyakorlóiskola az egyetemi hallgatók számára megfelelö felkészültséget az alábbi területeken?”, a következő válaszokat kaptuk. (3. sz. Tanári kérdöiv/17.)

\begin{tabular}{|l|l|l|l|}
\hline Kategóriák & $\begin{array}{l}\text { Választotta } \\
\mathbf{N}=\mathbf{1 6 6}\end{array}$ & $\begin{array}{l}\text { Százalékos } \\
\text { gyakoriság }\end{array}$ & Rangsor \\
\hline Pedagógiai tudás & 14 & $8,4 \%$ & 4. \\
\hline Pszichológiai tudás & 2 & $1,2 \%$ & \\
\hline Szaktárgyi tudás & 11 & $6,6 \%$ & 6. \\
\hline $\begin{array}{l}\text { Szakmódszertani } \\
\text { (tantárgypedagógia) tudás }\end{array}$ & 25 & $15,1 \%$ & 1. \\
\hline Pedagógiai tervezés & & & \\
\hline Óravezetés & 12 & $7,2 \%$ & 5. \\
\hline A diákok teljesítményének értékelése & 3 & $13,9 \%$ & 3. \\
\hline Tanítási módszerek & 23 & $1,8 \%$ & 10. \\
\hline Munkaformák & 24 & $14,5 \%$ & 2. \\
\hline Tanári kommunikáció & 14 & $8,4 \%$ & 4. \\
\hline Tanári (ön)reflexió & 12 & $7,2 \%$ & 5. \\
\hline Fegyelmezés & 5 & $3,0 \%$ & 8. \\
\hline Differenciálás & 3 & $1,8 \%$ & 10. \\
\hline Kollégákkal való együttmúködés & 2 & $\mathbf{4 , 2 \%}$ & 7. \\
\hline Adminisztrációs feladatok & 2 & $1,2 \%$ & 11. \\
\hline Osztályfónöki feladatok & 1 & $1,2 \%$ & 11. \\
\hline Tehetséggondozás & 4 &, $6 \%$ & 12. \\
\hline Felzárkóztatás & 2 & $\mathbf{2 , 4 \%}$ & $\mathbf{9}$. \\
\hline
\end{tabular}

10.13. táblázat: Az egyetemi hallgatók felkészültségének biztosítása a gyakorlóiskolában a pedagógusok megítélése szerint 
Összesen 166 válasz érkezett kérdésünkre (13. táblázat). A különleges bánásmódot igénylő gyermekek szempontjából érdekes kategóriákat kiemeltük táblázatunkban. A gyakorlóiskola az általunk kutatott területeken kevésbé biztosítja a hallgatók felkészültségét a többi kategóriához képest. A differenciálás a 7. helyet foglalja el a rangsorban, a tehetséggondozás és felzárkóztatás pedig a 9. és 11. helyre kerültek. Leginkább szakmódszertani felkészültséget nyújt, valamint az óravezetés, munkaformák és tanítási módszerek megismertetését tartja elsődleges céljának. A pedagógusok válaszai alapján elmondható, hogy ezt a területet kevésbé helyezik előtérbe a hallgatók felkészítésénél, pedig nagyon fontos lenne, hogy mielőtt valóban munkába állnak, kapjanak valamilyen mintát a kiemelt figyelmet igénylő tanulókkal történő bánásmódra is.

Az alábbi ábrákon (8.-10. ábra) az egyetemi képzés és a gyakorlat tartalma közötti összhangot szerettük volna összefüggésbe állítani a differenciálással, tehetséggondozással és felzárkóztatással. Amint láthatjuk, a kevés választási szám miatt a kettő között nem mutatható ki összefüggés. Annyit azonban elmondhatunk, hogy azok a pedagógusok, akik a hallgatók felkészítését ezeken a területeken kevésbé ítélték fontosnak, vagyis nem választották, igazán azt sem tudták megítélni, hogy milyen az egyetem és a gyakorlatok tartalma közötti összhang. Megfigyelhetjük mindhárom táblázatban a hasonló arányú nem válaszokat, s arra a következtetésre juthatunk, hogy a tanárok nem igazán tudják eldönteni a gyakorlati képzés és az egyetem által oktatott pedagógiai, pszichológiai és szakmódszertani tárgyak közötti kapcsolatot. Talán ebben a kontextusban megemlíthetjük, hogy ez valószínủleg annak tudható be, hogy a gyakorlóiskolában tanító pedagógusok sem igazán ismerik az egyetemen oktatott tantárgyakat, azok tematikáját. Ezáltal nem tudják megítélni sem, hogy megfelelö-e a képzési tartalom és a gyakorlatok közötti összhang.

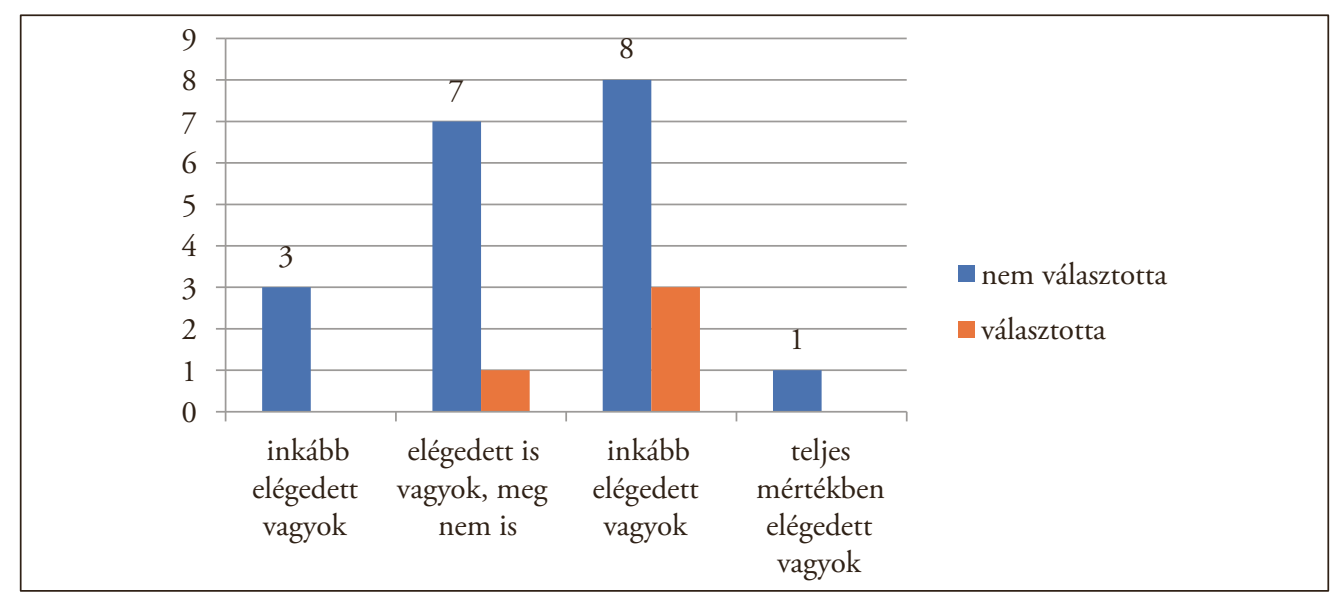

10.8. ábra: Az egyetemi képzés tartalma és differenciálás 


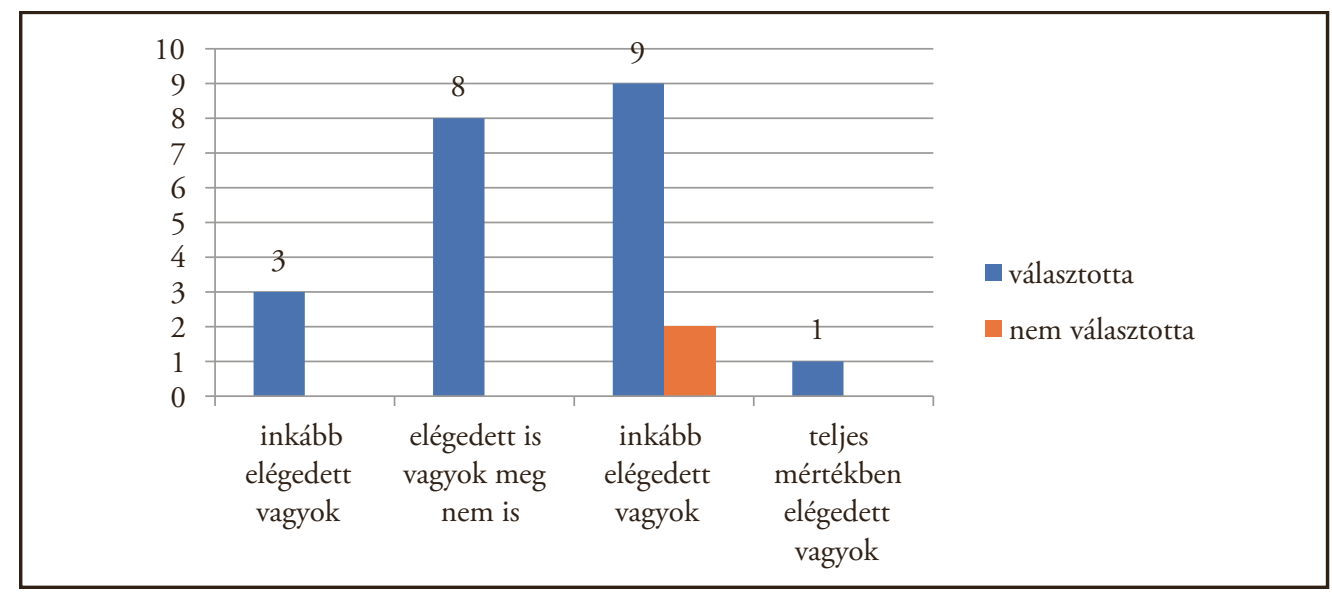

\section{9. ábra: Az egyetemi képzés tartalma és tehetséggondozás}

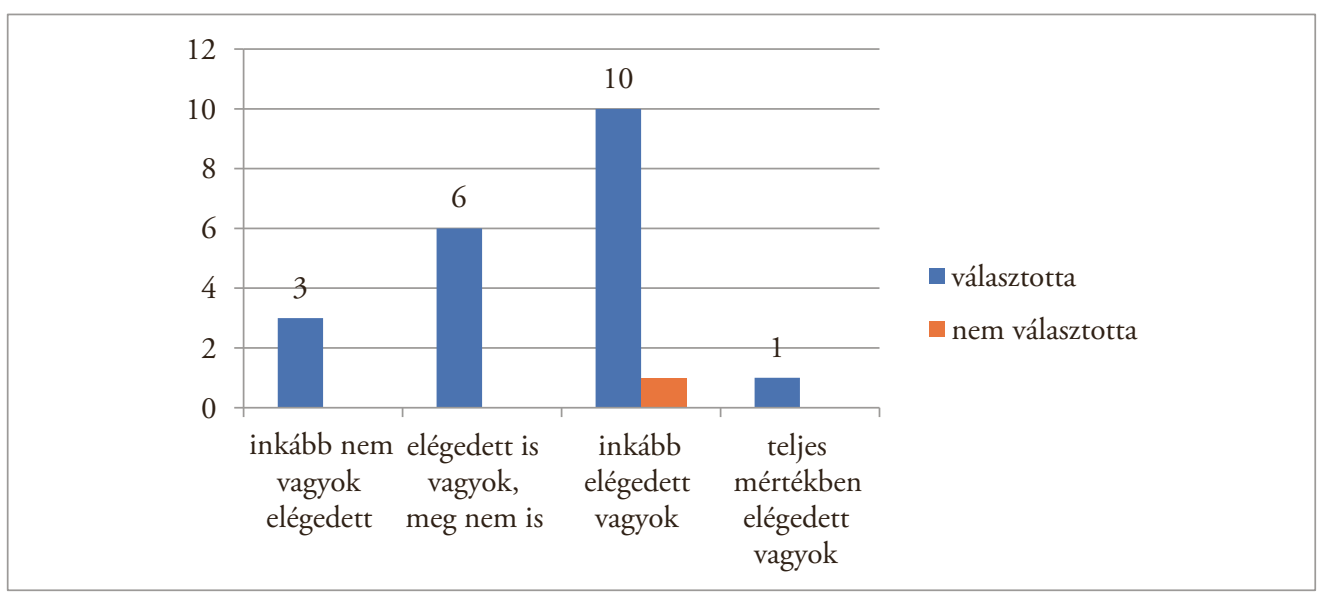

10.10. ábra: Az egyetemi képzés tartalma és felzárkóztatás

Arra a kérdésre, hogy „Mennyire ért egyet az alábbi állitásokkal az iskolai gyakorlatai vonatkozásában?”, vagyis mennyire fejlődött a gyakorlóiskolában eltöltött hospitálások és tanítási órák alkalmával, a következő válaszokat kaptuk. (Tanárjelölti kérdöiv/8). 


\begin{tabular}{|c|c|c|c|c|c|c|}
\hline Kategóriák & 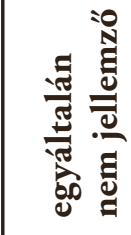 & 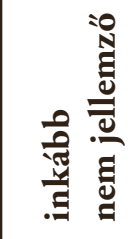 & 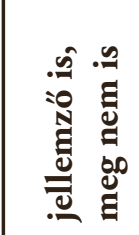 & 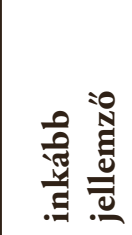 & 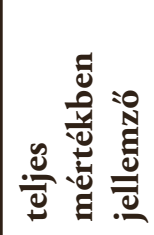 & 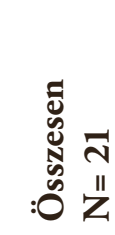 \\
\hline $\begin{array}{l}\text { Fejlődtem a tanórai } \\
\text { differenciálás terén. }\end{array}$ & 3 & 1 & 7 & 6 & 3 & 21 \\
\hline $\begin{array}{l}\text { Fejlődtem a tehetség- } \\
\text { gondozás terén. }\end{array}$ & 4 & 4 & 8 & 0 & 5 & 21 \\
\hline $\begin{array}{l}\text { Fejlődtem } \\
\text { a felzárkóztatás terén. }\end{array}$ & 4 & 4 & 11 & 0 & 2 & 21 \\
\hline
\end{tabular}

\subsection{3. táblázat: A hallgatók megítélése az iskolai gyakorlatokra vonatkozó fejlődésükről}

Összesen 21 értékelhető választ kaptunk kérdésünkre (13. ábra), amely ugyan nem túl sok, mégis megvilágítás alá helyezi, hogy vannak-e kiugró különbségek, eltérések, amelyeket érdemes lenne fontolóra venni a későbbiekben s beépíteni az egyetemi és a gyakorlati képzésbe is. Következtetésként azt vonhatjuk le táblázatunkból, hogy a hallgatók nem igazán tudják megítélni, hogy ezeken a területeken mennyire fejlödtek a gyakorlat során. A legtöbb válasz a „jellemző is, meg nem is” köztes kategória volt, ami arról tanúskodik, hogy eléggé bizonytalanok az e területeken történő fejlődésükről. Néhányan úgy érezték, fejlődtek, mások egyáltalán nem gondolták, hogy a gyakorlat során kaptak volna mintákat a kiemelt figyelmet igénylő tanulókkal való bánásmódra.

Kíváncsiak voltunk arra is, hogy ezekkel a válaszokkal összefüggésbe hozhatóak-e a hallgatók hospitálásai során látott és megvalósított tevékenységek. A következő kérdések kerültek összevetésre: „Hospitálásai során az alábbi tevékenységek közül melyeket látta?” „Gyakorlótanitása során az alábbi tevékenységek közül melyek megvalósitásában vett részt?" (Tanárjelölti kérdöiv/10, 11) Kérdésünkre 19 fö adott választ, azonban nagyon egyértelmű kép látszik kirajzolódni a kapott adatokból. Tehetséggondozó foglalkozást 4-en láttak, 2-en részt is vettek ilyenen. A felzárkóztatás esetében 1:2 a differenciált foglalkozás esetében 3:3 az arány.

Ezek az eredmények összefüggést mutatnak a pedagógusok megítélésével is. Válaszaikban szintén inkább a szakmódszertani felkészülést, tervezést, értékelést tartották fontosnak a hallgatók gyakorlóiskolai képzésénél. Kevésbé fordítanak időt a hallgatók ilyen irányú képzésére. A tehetséggondozó foglalkozáson való részvételt választották a legtöbben, de ez a szám sem mondható magasnak, hiszen mindössze 4 fó jelölte az igen választ. A többi kategóriánál ez még alacsonyabb értéket mutat. Nem mondható jobbnak a megvalósított tevékenységek aránya sem a téma szempontjából. A hallgatók csak igen kevés számban 
vettek részt a gyakorlóiskolában a kiemelt figyelmet igénylő tanulókkal való foglalkozásokon vagy differenciált tanítási óra megvalósításában.

Vizsgálatunk tárgyát képezte az is, hogy az egyetemi képzés és a gyakorlóiskola vajon milyen mértékben biztosítja a hallgatók felkészültségét az általunk vizsgált területeken (Tanárjelölti kérdöiv/17, 18). S ezzel párhuzamba állítottuk azt is, hogy ugyanezeken a területeken mennyire érzik magukat felkészültnek (Tanárjelölti kérdöiv/19).

\begin{tabular}{|l|l|l|l|}
\hline $\begin{array}{l}\text { Kategóriák } \\
\text { N = 19 }\end{array}$ & $\begin{array}{l}\text { Egyetemi felké- } \\
\text { szítés a tanári } \\
\text { professzióra } \\
\text { Gyakoriság (fó) }\end{array}$ & $\begin{array}{l}\text { Gyakorlóiskolai } \\
\text { felkészítés a tanári } \\
\text { professzióra } \\
\text { Gyakoriság (fó) }\end{array}$ & $\begin{array}{l}\text { Felkészültség } \\
\text { Gyakoriság (fó) }\end{array}$ \\
\hline Differenciálás & 3 & 4 & 1 \\
\hline Tehetséggondozás & 4 & 2 & 2 \\
\hline Felzárkóztatás & 1 & 1 & 0 \\
\hline
\end{tabular}

10.14. táblázat: A hallgatók felkészítése és felkészültsége a tanári professzióra

Táblázatunkban megfigyelhetjük (14. táblázat), hogy a választási arány nem mondható túl magasnak az általunk vizsgált területeken. Alig néhány hallgató érezte úgy, hogy a differenciálás vagy a tehetséggondozás terén készítették volna fel a leginkább a tanári professzióra. Még alacsonyabb az a szám, amely a felzárkóztatásra vonatkozik. Ezekkel az adatokkal párhuzamosan megfigyelhetjük azt is a táblázat 4. oszlopában, hogy szinte alig van olyan hallgató, aki felkészültnek érezné magát az általunk vizsgált terület valamelyikén. Ezek az adatok segítenek bennünket abban, hogy igazolják némi változtatás szükségességét a hallgatók ilyen irányú felkészítését illetően.

Végezetül megkérdeztük a hallgatókat arról, hogy mennyire elégedettek az egyetemi képzés és a gyakorlat tartalma közötti összhanggal. A 20 válaszadó által nyújtott adatok azonban elég árnyalt képet mutatnak számunkra. 


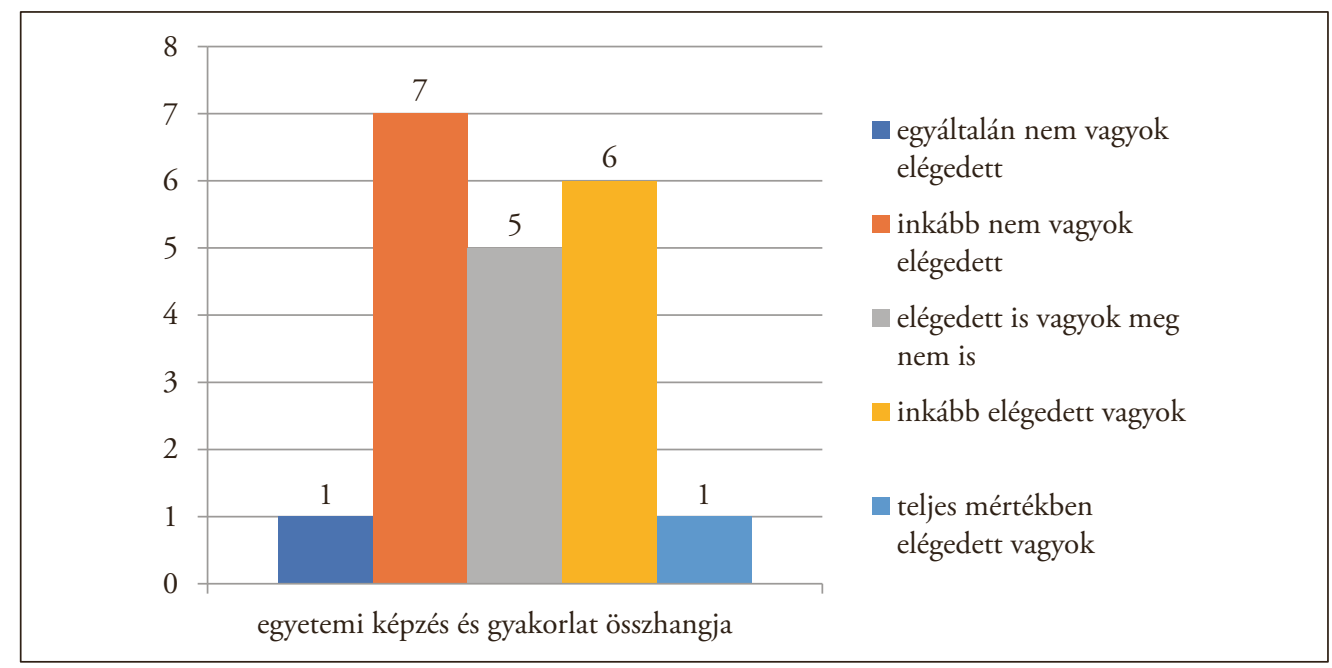

10.11. ábra: Az egyetemi képzés és a gyakorlati képzés összhangja a hallgatók véleménye szerint

A fenti ábrán látható (11. ábra), hogy a válaszadók nem igazán tudták egyértelműen megítélni az egyetemi képzés és a gyakorlat közötti összhangot. Következtetésként arra juthatunk, hogy vannak még hiányosságok ezen a területen. Ha nagyobb összhangban lenne a kettő, valószínűleg mind a pedagógusok (8.-10.ábra), mind a hallgatók könnyebben hoznának ítéletet az állításról. Ez lehet az oka, hogy nem kaptunk egyértelmü válaszokat egyik célcsoport tekintetében sem.

A hallgatók véleményeiből, összevetve a pedagógusok válaszaival nagyon tanulságos információk láttak napvilágot. A téma aprólékosabb felderítése talán még érdekesebb lehetne további hallgatók bevonásával, de ne feledjük el, hogy a kutatásunk célja nem a teljes hallgatóság mérése volt, sokkal inkább az érdekességek feltárása, kiemelten abból a szempontból, hogy egy szakmai fejlesztő iskola létrehozásához mely területek fejlesztése lenne célszerü.

Kutatásunkban arra is szerettünk volna választ kapni, hogy a szülők mit gondolnak a tehetséggondozásról, felzárkóztatásról a gyakorlóiskolában. A következő kérdéseket fogalmaztuk meg számukra: „Kérjük, értékelje, hogy mennyire tartotta fontosnak az alábbi tényezőket, amikor a gyakorlóiskolát választotta a gyermeke számára!” „Kérjük, értékelje, hogy mennyire elégedett most ugyanezekkel a tényezökkel!” (Szülöi kérdöiv/7., 9.) 


\begin{tabular}{|l|l|l|l|}
\hline $\begin{array}{l}\text { Kategóriák } \\
\mathbf{N}=\mathbf{2 4 7}\end{array}$ & $\begin{array}{l}\text { Nem volt fontos } \\
\text { százalékos gyako- } \\
\text { riság (\%) }\end{array}$ & $\begin{array}{l}\text { Közepesen fontos } \\
\text { volt százalékos } \\
\text { gyakoriság (\%) }\end{array}$ & $\begin{array}{l}\text { Nagyon fontos } \\
\text { volt százalékos } \\
\text { gyakoriság (\%) }\end{array}$ \\
\hline Felzárkóztatás & 7,7 & 24,7 & $\mathbf{6 7 , 5}$ \\
\hline $\begin{array}{l}\text { Versenyeken } \\
\text { való részvétel } \\
\text { lehetősége }\end{array}$ & 10,1 & 52,6 & 37,2 \\
\hline
\end{tabular}

10.15. táblázat: A szülők nézetei az iskolaválasztás szempontjából

A táblázatból leolvasható (15. táblázat), hogy a szülők a felzárkóztatást egy igen fontos szempontnak ítélik meg. A versenyeken való részvétel lehetősége inkább közepesen fontos számukra, de 37,2\%-uk nagyon fontosnak tartja. Összességében elmondható, hogy mindkét szempont jelentősége fontos lehet az iskolaválasztás szempontjából.

Az alábbi táblázatban megfigyelhetjük (16. táblázat), hogy ugyanezen szempontokkal jelenleg mennyire elégedettek a szülők.

\begin{tabular}{|c|c|c|c|c|c|c|}
\hline $\begin{array}{l}\text { Kategóriák } \\
\mathbf{N}=\mathbf{2 4 7}\end{array}$ & 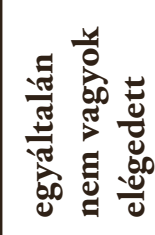 & 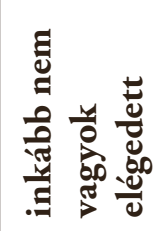 & 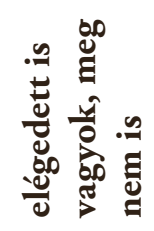 & 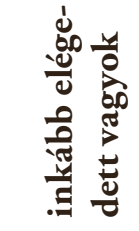 & 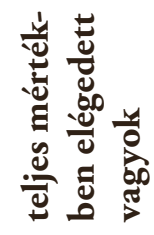 & 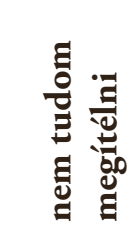 \\
\hline $\begin{array}{l}\text { Felzárkóztatás } \\
\text { gyakoriság (fó) }\end{array}$ & 8 & 14 & 44 & 63 & 91 & 31 \\
\hline $\begin{array}{l}\text { Felzárkóztatás } \\
\text { százalékos } \\
\text { gyakoriság (\%) }\end{array}$ & 3,2 & 4,0 & 17,8 & 25,5 & 36,8 & 12,6 \\
\hline $\begin{array}{l}\text { Versenyeken } \\
\text { való részvétel } \\
\text { gyakoriság (fö) }\end{array}$ & 2 & 2 & 21 & 64 & 125 & 33 \\
\hline $\begin{array}{l}\text { Versenyeken } \\
\text { való részvétel } \\
\text { százalékos } \\
\text { gyakoriság (\%) }\end{array}$ & 0,8 & 0,8 & 8,5 & 25,9 & 50,6 & 13,4 \\
\hline
\end{tabular}

10.16. táblázat: A szülők elégedettsége a tehetséggondozással és felzárkóztatással

Érdekes megfigyelni, hogy a felzárkóztatással a válaszadók kb. 60\%-a elégedett, ez nagyjából arányos azzal a 67,5\%-kal, akik szerint fontos iskolaválasztás szempontjából 
a felzárkóztatás megfelelő szinten való működése. Ami viszont még szembetűnőbb, hogy a szülők több mint 70\%-a elégedett a versenyeken való részvételi lehetőségek biztosításával a gyakorlóiskolában, holott mindössze 37,5\%-uk tartotta ugyanezt a szempontot fontosnak az iskolaválasztásnál.

Összességében megfogalmazhatjuk, hogy a szülők nagy része megfelelő színvonalúnak tartja a gyakorlóiskolában folyó kiemelt figyelmet igénylő tanulókkal való bánásmódot. Úgy érzik, gyermekeik lehetőséget kapnak versenyeken való részvételre, és a felzárkóztatásban is segítik őket tanáraik.

\section{5. Összegzés}

Tanulmányunkban a különféle iskolai dokumentumokat elemeztük, valamint a pedagógusok, hallgatók, diákok és szülők nézeteit vizsgáltuk arra a kérdésre keresve a választ, hogy a kiemelt figyelmet igénylő tanulókkal való bánásmód szempontjából miért jó egy gyakorlóiskola. Feltérképeztük, hogy az érdekelt felek nézeteinek figyelembevételével az Eszterházy Károly gyakorlóiskola szakmai fejlesztő iskolává válásához milyen lépéseket szükséges megtenni a jövőben.

A rendelkezésre álló adatok alapján a következő kijelentéseket fogalmazhatjuk meg:

- az iskolai dokumentumok és a pedagógusok is azt vallják, hogy rendkívül fontos feladatuk a kiemelt figyelmet igénylő gyermekek megfelelő fejlesztése és az egyéni bánásmód megvalósítása a gyakorlóiskolában;

- a pedagógusok nagy része tart egyéni foglalkozásokat tanulóinak sokféle módszert alkalmazva a tehetséges tanulók és lemaradók felzárkóztatása érdekében;

- a gyakorlóiskolában tanítók kiemelten fontosnak tartják az egyéni képességfejlesztést, s ezzel összefüggően az óráik túlnyomó részében a diákok egyéni képességeit helyezik előtérbe, tudatosan figyelnek a fejlesztésre;

- a pedagógusok eltérő nézeteket vallanak a tehetséggondozás és felzárkóztatás témakörében zajló továbbképzésekről, és az iskolai elvárásokkal ellentétben tehetséggondozással kapcsolatos tréningeken vennének részt szívesebben;

- a pedagógusoknak nagyobb igénye lenne olyan továbbképzésekre, amelyeket saját maguk választhatnak ki, nem az intézmény követeli meg tőlük;

- a tanulók nézetei szerint a gyakorlóiskola magas szinten végzi a tehetséges gyermekek fejlesztését, rengeteg versenyen vesznek részt, viszont kevésbé érzik egyértelműnek az egyéni bánásmód, a tanulásban való segítségnyújtás érvényesülését;

- hiányolják a tanórákon az egyéni, személyre szabott feladatokat, és többségük tanulmányi 
eredményének javulását nem a fejlesztő óráknak, sokkal inkább saját szorgalmának és a téma érdekességének tudja be;

- a hallgatók felkészítését a kiemelt figyelmet igénylő tanulók fejlesztésére kevésbé tartják fontosnak a pedagógusok, s a hallgatók sem érzik magukat e területen felkészültnek;

- az egyetemi képzés és a gyakorlati képzés közötti összhangot közepesnek ítélik a pedagógusok és hallgatók egyaránt, nem rajzolódik ki a két intézmény közötti együttműködés;

- a szülők számára az iskolaválasztás szempontjából fontos a felzárkóztatás, viszont kevésbé elégedettek ugyanezzel a gyermekük iskolába kerülése után;

- a versenyeken való részvételt nem tartják olyan fontos szempontnak iskolaválasztáskor, ugyanakkor gyermekük bekerülése után sokkal inkább elégedettek azzal.

\section{Javaslatok}

A szakmai fejlesztő iskolává válásához javaslatként fogalmazzuk meg a fenntartó és az iskolavezetés számára:

- az egyetem és az iskola szélesebb körű együttműködésének ösztönzését mind a két intézmény, mind pedig az intézményekben dolgozó pedagógusok és oktatók között,

- az egyetemi képzés és a gyakorlatok összehangolását;

az iskolavezetés számára:

- a hallgatók tanári professzióra való felkészítéséhez a gyakorlóiskolában lévő lehetőségek kiaknázását, a kiemelt figyelmet igénylő tanulók fejlesztésének megfigyelési lehetőségét és gyakorlatban történő fejlesztését,

- a hallgatói visszacsatolások beépítését gyakorlati képzésük fejlesztésébe,

- az iskola segítségével történő tanulói előrehaladás, fejlődés több csatornán történő kommunikálását a szülők és diákok felé egyaránt,

- a pedagógusok továbbképzésének támogatását az általuk lényegesnek tartott témákban;

a pedagógusok számára:

- a diákok számára az egyéni segítségnyújtás magasabb szintre emelését, nemcsak a kiemelt figyelmet igénylők, hanem minden tanuló esetében,

- a hallgatók intenzívebb bevonását az iskolában megvalósított tehetséggondozásba, felzárkóztatásba, differenciált tanórai tevékenységekbe,

- az egyetemi oktatókkal való szorosabb kapcsolattartást, az oktatási tartalmak összehangolása, valamint az egyetem és gyakorlóiskola szakmai munkájának folyamatos felülvizsgálata, az esetenként szükséges korrekciók elvégzése érdekében. 


\section{Felhasznált irodalom}

Báthory Zoltán (1997): Tanulók - Iskolák - Különbségek. Egy differenciális tanításelmélet vázlata. Okker Kiadó, Budapest.

Csapó, B., Fejes, J. B., Kinyó, L. és Tóth, E. (2014): Az iskolai teljesítmények alakulása Magyarországon nemzetközi összehasonlításban.

Falus Iván (1998): Didaktika. Nemzeti Tankönyvkiadó, Budapest.

Falus Iván (2003): A pedagógussá válás folyamata. ВІСНИК ОСВІТИ, 140.

Kotschy Beáta (2003): Szakmai fejlesztő/fejlődő iskolák - a pedagógusképzés megújításának egy lehetősége, Pedagógusképzés 1. évf. 1-2. sz 109-117.

Kotschy Beáta (2007): A pedagógusok szakmai fejlődésének új perspektívái. In Falus Iván: A tanárrá válás folyamata Budapest, Gondolat.

Lannert Judit (2004): Minőség, eredményesség, hatékonyság. Új Pedagógiai Szemle, 12. $3-15$.

Levine, M. (1998): Designing Standards That Work for Professional Development Schools. Commissioned Papers of the NCATE PDS Standards Project. National Council for Accreditation of Teacher Education, 2010 Massachusetts Avenue, NW, Suite 500, Washington, DC 20036-1023.

Murray, F.B. (1993): „All or none” criteria for professional development schools. In Altbach, P. G., Petrie, H. G., Shujaa, M. J. és Weis, L. (Eds.): Educational Policy:V.7, Number 1. Professional development schools (61-73.) Newbury Park, CA: Corwin Press https://doi.org/10.1177/0895904893007001005

NCREST (1993): Vision statement. PDS Network News, 1 (1), 3-4.

Young, L. S. J. (1990): Tomorrow's schools: principles for the design of professional development schools: a report. Holmes Group.

OECD (2013): PISA 2012 results: Excellence through equity: Giving every student the chance to succeed (Vol. II). Paris: OECD.

Réthy Endréné (2020): A méltányos pedagógia kutatási aspektusai a tanítás-tanulás folyamatában. Neveléstudomány, 4. 21-34.

Réthy Endréné és Vámos Ágnes (2006): Esélyegyenlőtlenség és méltányos pedagógia. In M. Nádasi Mária (szerk.): A gyakorlati pedagógia néhány alapkérdése. Bölcsész Konzorcium, Budapest.

Strédl Terézia (2016): Az iskolakezdés problémaköre. Edukacja-Technika-Informatyka, 7(1), 258-268. https://doi.org/10.15584/eti.2016.1.36 
2011. évi CXC. Törvény a nemzeti köznevelésről

Eszterházy Károly Főiskola Gyakorló Általános, Közép-, Alapfokú Művészeti Iskola és Pedagógia Intézet (2016), Nevelési program https://drive.google.com/file/d/0BzreRR__Yf1pX1ZRT3kwcUFuTDg/view Eszterházy Károly Főiskola Gyakorló Általános, Közép-, Alapfokú Művészeti Iskola és Pedagógia Intézet (2016): Szervezeti és Müködési Szabályzat https://drive.google.com/file/d/0BzreRR__Yf1pT0RrcHY5UjhFNXM/view Eszterházy Károly Főiskola Gyakorló Általános, Közép-, Alapfokú Művészeti Iskola és Pedagógia Intézet: Munkaterv (2016/2017) https:/drive.google.com/file/d/0BzreRR__Yf1pc2MwcldlQ3B0WEU/view 15/2013. (II. 26.) EMMI rendelet a pedagógiai szakszolgálati intézmények működéséről http://www.kozlonyok.hu/nkonline/MKPDF/hiteles/mk13032.pdf https://www.oktatas.hu/kozneveles/kerettantervek/2020_nat/iranyelvek_alapprogramok 